\title{
DOUTRINA
}

\section{Curso de Direito Comercial}

\section{Brasílio Machado}

(Entre os professôres de maior nomeada de Faculdade de Direito de São Paulo destacou-se Brasílio Machado, como esicritor de grandes méritos e, sobretudo, como orador de altos vôos, ha vido como o príncipe da tribuna judiciária de sea tempo.

Promovido, em 30 de setembro de 1890, a professor catedrático de direito natural, na vaga de SÁ E BENEvides, imediatamente se transferiu para a cadeira de direito comercial na terceira série do curso de cúências jurídicas. que data, e melhor é repetir palavras de sieu filho Alcântara Machado, "em verdade, o seu professorado. Lecionou a matéria durante vinte anos. Foi êle, por assim dizer, quem inaugurou o ensino do direito mercantil na Faculdade de São Paulo. $O$ velho Falcão não deixou vestigio de sua passagem pela cátedra. Aintônio Ciarlos, que lhe sucedeu e antecedeu a Brasílio, era dotado de inteligêncía brilhante, mas não se dava à macada de estudar. Limitava-se a ler anotaçốes de OrLaindo e páginas de Massé, quando não consumia a hora regimental em divagações intermináveis, o que, na gíria acadêmica, se chamava "encher linguiça".

Em 1906, organizou Brasílro Machado o "programa de um curso sistemático de direito comercial", que assim justificou: 
"O curso desta cadeira foi metodizado sôbre um programa novo, que bem corresponde às exigências da lei e satisfaz as necessidddes do ensino. Criando duas cadeiras de direito comercial no curso de ciências jurídicas, a lei nẩo pretendeu por isso mesmo dividir as matérias aliás vastîssimas que dquela disciplina inclui - fêz de uma cadeira a sequência da outra, sem linhas demarcatórias, sem soluçâo de continuidade no ensino: não distribuiu, como a muitos parece, para o terceiro o conjunto de preceitos que afetam mais diretamente ao comércio em geral e ao comércio terrestre, reservando para o quarto ano, seja qual fôr o intervalo deixado no curso anterior, o doutrinamento exclusivo do direito comercial maritimo e do instituto das falências. Seria fragmentar em demasia a unidade da ciência e destarte ministrar um ensino defeituoso e quebrado em seu nexo científico. A lei também não contraiu ao modêlo do código a distribuiçẩo das matérias do programa; êste pode receber uma organização live, contanto que, dentro das raids do direito comercial, se não espraie em esplanações casuisticas, com detrimento das generalizações $e$ das grandes sinteses, que traduzem a verdadeira orientação de tôdas as ciências. Mas, por outro lado, não é menos certo, que extenso e abundante como é o programa completo do ensino do direito comercial, um curso embora de dois anos está longe de exgotá-lo.

Nesses têrmos, o programa que menos inconvenientes oferece é aquêle que, respeitando a peculiaridade do comércio terrestre, combine num só corpo o ensino, paralelo de um e de outro, com $a$ indispensável precedência de umd parte introdutiva ou geral em que fiquem bem acentuadas as linhas comuns que ligam aquelas duas grandes divisões do comércio. Foi nesse plano que ajustei definitivamente o programa atual".

o programa espraiou-se em consonância com êsse critério, mast nấo foi jamais executado, não 
porque faltasse competência ao professor, senão porque, e diga-o ainda uma vez AlcÂNTARA MACHADO, "por ser assim escrupuloso no preparo das lições, e também porque tinha de advogar para prover à subsistência da família, a que não podia acudir com os vencimentos mesquinhos dos professores daquele tempo, Brasílı 'nầo se distinguid pela assiduidade".

Essa falta de assiduidade impediu que o programa magistral se cumprisse; e o ensinamento. nos dois anos do curso, não foi além da introdução. As preleções de Brasíllo Machado, preparadas como se vê do esquema aqui em seguida reproduzido, foram brilhantes, como se prenunciaram pela aula inaugural do seu curso de direito comercial no ano letivo de 1897, publicada nesta mesma Revista, vol. V, págs. 135 a 155, que tão largd repercussão teve no pais. Nunca, porém, foram além da teoria dos atos de comércio.

Taquigrafadas e publicadas, as dos anos, le-. tivos de 1906 e 190\%, um dos estudantes de entầo, Waldemar Ferreira, resumiu, em caderno manuscrito, que ainda conserva, a matéria explicada nas dezesete preleções, que tantas foram as do ano letivo de 1906. Quiz lê-las, nesse resumo, o professor Sylvio Marcondes. Finda a ieitura devolveu êle o velho caderno ao seu dono. com a cópia datilografada de todo êle, na sua grafia modernizada, a fim de que se imprimisse nesta Revista, pois que bem o merecia, a despeito do tempo decorrido.

Pois que assim seja! 


\section{INTRODUÇÃO}

\section{Noções Elementares}

a) Necessidade econômica. Produção e consumo econômicos. Utilidades, riquezas, bens, mercadorias. Série intermediária: dos fenômenos da circulação econômica, seus modos de ação: - deslocação, transmissão. Indústria e suas espécies. A indústria locomotriz. Transporte por terra e por água.

b) Como circulam as riquezas pela transmissão: troca; comércio. O comércio através de sua evolução económica, desde o fenômeno inicial da troca até a organização complexa da indústria contemporânea. O comércio é produtivo.

a) O Direito Comercial, recaindo sôbre as relações individuais e recíprocas dos homens, numa sociedade constituída, é um ramo do Direito Privado, e não do Público. Mas, além de ser uma ramificação do Privado, é também positivo o Direito Comercial, do qual se podia dar como noção - a disciplina jứídica do comércio. $E$ isto dá ensanchas a que se pergunte: - que é o comércio?

O comércio pode ser considerado de dois modos: econômico e jurídico. A relação jurídica é simultânea com a econômica, e desta se parte para alcançar aquela. E, para tal, é preciso remontar a certos princípios, que regulam as ações humanas: - a ordem moral, a do interêsse e a de justiça.

O homem, para cumprir o seu dever, satisfazer o seu interêsse, ou atingir o ideal de justiça, tem, forçosamente, de assimilar do ambiente em que se desenvolve os elementos vitais, novas fôrças, - quer sejam fornecidas gratuitamente pela natureza, quer sejam delas um produto. De um lado a natureza, de outro o que se chama riqueza. 
Para adquirir fôrças, é necessário que o homem se aproprie das cousas que a natureza lhe oferece.

Há cousas materiais - que passam por transformações lentas, progressivas, sem serem imediatamente apropriadas. O trabalho é que as ađapta às necessidades do homem. Tôdas essas cousas, assim apropriadas pelo trabalho, chamam-se bens econômicos, e èstes podem ser bens comuns e de propriedade. Os bens comuns são inesgotáveis e são apropriados sem dispêndio de fôrças: a luz, o ar, a água; e os bens de propriedade são aquêles sôbre os quais pode recair o domínio de um particular, ao passo que, nos bens comuns, não pode haver um patrimônio particular. Há cousas que se consomem ràpidamente, como o pão, o trigo, a água, e outras que se consomem lentamente, como o vestuário, a casa. Há cousas materiais, sensíveis, apreendidas, percebidas pelo sentido, num sentido restrito, - e cousas imateriais, que só podem ser tocadas nos seus resultados materiais, como a receita do médico, a lição do professor, a tela do pintor.

Tôdas essas cousas formam os bens econômicos, e levam o cunho do fator - o trabalho, indispensável para a adaptação, em qualquer intensidade, quer seja muscular, mental ou intelectual. Todo o esfôrço do trabalho representa sempre um dispêndio de fôrça. É preciso estabelecer um equilíbrio entre as fôrças dispendidas e o seu resultado. A linha da menor resistência. O ideal é empregar-se pouco para obter grande resultado. Eor isso que se forma a lei da ciência econômica. "Mas nem sempre pode o homem, com o crescente progressivo das necessidades, conseguir êsse equilíbrio. Muitas vêzes se estabelece o deficit das fôrças.

Casos há, entretanto, em que mais se adquirem fôrças do que se perdem ou dispendem, e, então, pode-se fazer uma reserva de fôrças, formando o - capital econômico.

Para que o homem possa conseguir o equilíbrio: ou êle torna mais expansivo e produtivo o trabalho, ou faz uso 
da fraude e da violência. E êste não é ato lícito nas sociedades policiadas. Êle precisa desenvolver-se. Os agentes naturais fornecem a obra prima. O trabalho do homem, segundo Nièce, nada mais é que o esfôrço feito por êle para dar impulso à matéria. Dominando a matéria, pode o homem satisfazer as suas necessidades. Imprime-lhe movimento, dá orientação às cousas mecânicas. Muito embora o homem coordene, nunca poderia alcançar todos os bens econômicos para o seu desenvolvimento. Mas não se compreende o homem sem outro homem. É preciso o concurso dos homens. Nasce a cooperação, que pode ser: simples e complexa. Consiste a cooperação simples na reiteração $d \epsilon$ atos idênticos, como a deslocação de pêsos por guindastes. Os homens primitivos, os egípcios, construiram as duas pirâmides por meio dela. Não é êsse o ideal da Economia Política, e sim a coordenação das fôrças humanas, a indústria organizando muitas operações, com a divisão do trabalho. Vejamos alguns exemplos.

JoÃo Baptista SAY notou que a carta de jogar é resultado de 70 operacões diferentes. Imagine-se agora um operário para tal emprêsa. Quais nulos os seus esforços. Entanto, com a cooperação, com a divisão do trabalho, quantas cartas não se fazem num dia! Smith, visitando uma fábrica de alfinetes, observou que, para cada alfinete, há 18 operações. Prony resolveu organizar uma tábua logarítmica. Só, e para fazê-la de 1 a 200.000 , a sua vida não chegaria. Mas, reunindo um número de homens capazes para um tal empreendimento, e distribuindo as diferentes operações em diversas tarefas, levou a efeito o seu trabalho ao fim de quinze anos.

A coordenação, ou antes a cooperação simples não dá resultado análogos, pois, para explicar o enorme desenvolvimento da indústria moderna, basta a cooperação complexa, que se distribui em duas grandes operações: a decomposição e distribuição das tarefas parcelares em ordem a determinar a criação de um produto, - e a coordenação 
dessas tarefas parcelares, dessas operações preparatórias, para formar o conjunto do trabalho - o produto.

Mas se o homem não pode viver sem consumir, sem adaptar às suas necessidades as utilidades econômicas; se o homem não pode consumir sem produzir, e não pode produzir sem o trabalho, - para que êle possa apropriar-se das utilidades econômicas, elemento adequado às suas necesidades, é indispensável que elas estejam ao seu alcance, à súa disposição, o que vale dizer em linguagem econômica: é necessário que as mercadorias que representam as utilidades estejam em comunicação com os mercados de consumo, é preciso relacionar os mercados em que os produtos e as utilidades se produzem com os mercados em que se consomem.

Quando se diz produção, e quando se diz consumo, quer-se dizer necessidade econômica. São dois fenômenos extremos. Faz-se mister um vinculo que relacione e aproxime êsses dois têrmos opostos, que explique a harmonia dêsses dois fenômenos. $\mathrm{O}$ fenômeno intermediário que os vincula, é a circulação das riquezas, dos produtos, das necessidades econômicas. Por isso é que a Economia Política se divide em quatro secções: a produção, a circulação, a distribuição e o consumo das riquezas.

Produzir riquezas ou necessidades econômicas é adaptar as cousas materiais ao uso, às nossas necessidades. Consumir essas utilidades é tornar efetiva a aplicação dessas utilidades às nossas necessidades: o pão que se come, a água que se bebe, são utilidades que se destroem, que se consomem em satisfação às necessidades da fome do homem. Mas é necessário estabelecer-se entre êsses dois extremos o que a Economia Política denomina - circulacão das riquezas. Como o produto tem um valor, êste valor é distribuido pelos fatores do mesmo produto, e então intervem a Economia Política sôbre a distribuição dos valores dos produtos pelos próprios produtores. 
O fenômeno intermediário da circulação das riquezas, que se denomina uma série de movimentos entre a produção e o consumo, realiza-se de dois modos distintos: ou essa circulação se opera mediante a deslocação das riquezas, das utilidades, dos bens econômicos, mudando o local do bem econômico em que êle se haja produzido para outro local onde deva ser consumido e aproveitado, e, neste caso, trata-se da locomoção, do transporte, da indústria locomotriz; - ou essa circulação se opera pela passagem de um proprietário para outro proprietário, de um individuo para outro indivíduo, dessa cousa, dessa utilidade, dêsse bem econômico - e temos a troca, que é o fenômeno fundamental da indústria comercial.

O trabalho da aproximação do mercadò de produção do mercado de consumo, trabalho singular reunido à coòperação dos agentes naturais, êste trabalho coletivo em que se reunem em esfôrço comum os trabalhos alheios aos trabalhos próprios, não explicaria a expansão econômica, não determinaria o equilíbrio entre a produção e o consumo, si não fôsse organizado, si êsse trabalho coletivo não fôsse combinado, si êsses trabalhos se não submetessem a certas regras e prescrições duma verdadeira mecânica. E è como nascem as indústrias.

A indústria nada mais é do que o trabalho organizado. ẻ o concurso dos diferentes fatores de produção em ordem. a criar uma certa e determinada utilidade, certas e determinadas produções. De moảo que se pode dizer que a cada espécie de produto corresponde uma indústria especial. Há classificá-las, entretanto, por mais diversos que sejam os seus processos. Encontra-se esta primeira classificação: indústrias acumulantes e indústrias distribuintes. Indústrias acumulantes são aquelas pròpriamente de produção: como, por exemplo, uma fábrica, os produtos da natureza. Essas produçôes pertencem às indústrias acumulantes. Indústrias distribuintes são as que põem em movimento a massa dos produtos das indústrias de produção, como por 
exemplo, a circulação, a troca dos produtos pela indústria comercial e pela indústria locomotora.

A classificação mais comum entre os economistas, distribue a indủstria nas seguintes espécies: em primeiro lugar, a indústria extrativa, na qual o homem colhe, recolhe e se apropria dos produtos naturais, sem que, entretanto modifique a essência, a substância íntima dêsses mesmos produtos, como a caca, a pesca, a colheita da borracha no Amazonas ou no Pará.

Além da indústria extrativa, que compreende a indústria florestal, o corte das madeiras. a indústria metalúrgica, a exploráção das minas, há ainda as indústrias agrícolas. Estas também recebem, colhem e se apropriam. dos produtos naturais, mas, por meio de processos físicos e químicos, como que dirigem, domesticam e fecundam as fôrças naturais, de modo a ser o produto um resultado da cooperação do trabalho do homem com as fôrças da natureza. A indústria agrícola compreende, não só a indústria agrícola, pròprimente dita, como a indústria pastoril.

A indústria fabril ou manufatureira se apropria da. matéria prima que as outras indústrias lhe fornecem, p̀ara afeiçoar, transformar, alterar, modificar completamenteessa mesma matéria.

A indústria comercial reune e distribui os produtos das. outras indústrias.

A indústria locomotriz transporta dos mercados de produção para os mercados de consumo os produtos que a indústria comercial reuniu e distribuiu. A indústria locomotriz, ou de transporte mais pròpriamente dito, sofre duas grandes divisões: a indústria de transporte por água, que é o centro de tôdas as operações e obrigações mercantís, que formam o Direito Comercial Marítimo, e a indústria de transporte por terra, que. na aproximação dos produtos, dá. lugar a contratos do Direito Comercial Terrestre. 
b) Como vimos atrás, a diversidade das zonas em que cada produto se cria explica o fato da deslocação das riquezas, e a diversa aptidão dos homens para o trabalho explica a intervenção do que se chama - troca, que é o segundo modo da circulação das riquezas e o fato terminal do comércio. E' ela que estabelece o equilíbrio entre a produção e o consumo, é um fenômeno puramente humano. Letourneau, materialista, procurando estabelecer, entre os atos do homem pròpriamente ditos e os dos animais, uma certa relação, disse que os atos humanos nada mais são do que uma evolução dos atos praticados pelos animais; entretanto, com relação ao comércio, êle não encontra entre os animais fato algum donde se possa inferir que o ato comercial provenha dêsses atos dos brutos. $\mathrm{O}$ ato troca é puramente humano; começou pelas operações mais simples: o produtor mesmo trocava produto contra produto. Suponhamos que um lavrador produzisse cereais e precisasse de instrumentos agrários. Dirigia-se ao industrial para adquirí-los, of erecendo-lhe, em troca, cereais. Mas como o industrial no momento não precisasse de cereais, a troca era impossível, por só provir da concidência de necessidades sôbre um ou dois produtos. Mas suponhamos ainda que o industrial precisasse. não de cereais, mas de panos, que o lavrador também não possuisse: era preciso que o lavrador fôsse procurar o fabricante de panos e os levasse como preço de permuta para o industrial. Complicava-se muito, pois, a operação de troca. Platão, querendo, um dia, ir ao Egito, e não tendo dinheiro para comprar a passagem, lembrou-se de obter com o produto dos óleos que possuia o dinheiro necessário para comprar passagem no navio. Havia no porto do Pireu alguns navios e a êstes propõe Platão o negócio: os carregadores do navio recusaram aceitar o negócio e Platão não pôde vender os óleos. A Ática estava abarrotada dêsse gênero de mercadoria. Forçoso era não fazer a viagem. Diante das exigências do filósofo, propuzeram-se levá-lo com os óleos para o Egito 
para, com o produto, pagar o preço do transporte. Para haver permuta de produtos é mister que êles sejam idênticos em pêso, número, medida e qualidade. Mas, como a troca só è possivel quando os produtos são diversos, precisa-se encontrar uma equação de valores - a verdadeira base das operações econômicas — o valor, que é a estimabilidade de uma cousa conforme a sua bondade absoluta ou relativa; é o maior ou menor grau de préstimo entre duas cousas que se trocam. Como estabelecer entre produtos diferentes essa equação de valores? Recorreu-se a um produto intermediário que servisse de medida de valor entre dois produtos de natureza diferente ou de valores diversos, e que facilitasse a operação da troca: é a que se chamou moeda. No princípio, os lavradores que criavam as riquezas cuja conservação era difícil, tinham necessidade de imediatamente as permutar, de trocar êsses produtos por outros de utilidade geral, de utilidade comum, cuja conservação fôsse mais fácil e menos dispendiosa, que não se deteriorassem, e então criou-se esta espécie de mercadoria intermediária, interveiu a função econômica da moeda, que era representada por cousas de uso comum: bois, carneiros, escravos. A palavra dinheiro é, em latim, pecunia, que vem de pecus, animal, gado, indicando a origem dessa mercadoria intermediária. Essas cousas de utilidade comum, porém, como bois, carneiros, escravos e outros objetos que primitivamente serviram de moeda, não ofereciam motivos de preferência nem as condições necessárias para que a moeda cumprisse a sua função econômica. Êsses objetos não eram homogêneos, variavam de indivíduo para indivíduo, não eram divísíveis, de modo que não se podia graduar o valor das cousas. Procurou-se, então, um objeto material que tivesse a homogeneidade necessária, fôsse divisível e tivesse um valor intrínseco em si para que pudesse exercer as duas funções principais - de meio de troca e de avaliador de utilidades, e vieram os metais, o bronze, o ouro, a prata, o níquel, que têm pequenino volume, pos- 
suem grande valor, são inalteráveis, divisiveis e homogêneos. A intervenção da moeda decompôs a operação da troca em duas operações distintas: a compra e a venda dos produtos, instituindo-se o contrato da compra e venda. A complexidade das trocas, em operações avultadas, de transações complicadas ou permanentes e incessantes, trouxe uma circulação enorme e custosa de numerário. Para evitar tudo isso, adveio o crédito, que entregava a prazo, segundo a promessa de pagamento em moeda, dentro de prazo e nas condições convencionadas entre o comprador e o vendedor. Podendo o emprêgo efetivo de numerário nas transações ser substituido por uma promessa a efetuar em prazo mais ou menos longo, parecia que estavam obviadas tôdas as dificuldades nascidas da complexidade das transações. Munido mesmo com a moeda ou o crédito, tinha o consumidor de ir diretamente aos mercados de produção: adquirir os objetos e transportá-los para seu domicílio. Isto consumia tempo, dava muita despesa, sendo preciso fazer longas viagens em um tempo em que não havia segurança nas vias de comunicação. $O$ fenômeno evoluiu. Apareceu um intermediário entre o produtor e o consumidor encarregado de adquirir nos mercados de produção grandes provisões e transportá-las aos mercados de consumo. Eis o fenômeno do comércio, que a princípio se confundia com a indústria de transporte, porque os comerciantes iam diretamente aos mercados adquirir as mercadorias, trazendo para os mercados de consumo as utilidades, que distribuiam na proporção do consumo. E era também ambulante. Mais tarde tornou-se estacionário em razão dos grandes depósitos do comércio a grosso ou por atacado. Como os comerciantes a grosso não pudessem ir a cada um dos consumidores oferecer os gêneros, o comércio a retalho veị a satisfazer esta necessidade. O fenômeno econômico do comércio completou o fenômeno econômico da troca, pelo que não é raro dizer-se que: o comércio tem por função fundamental a troca de produto contra produto, primeiro, e de- 
pois a compra e venda pela moeda e a compra e venda a crédito, e o crédito e a moeda e a troca servindo como funcão para a intervenção do comércio, a grosso ou a retalho.

O comércio é produtivo. Houve uma escola econômica. a escola fisiocrática, que entendia só existir valor na terra e nos seus produtos. Nem os produtos humanos nem o capital tinham valor. Para esta escola o comércio não tinha uma função produtiva. Mais tarde apareceu a escola dos socialistas dizendo que o comércio nada mais é do que um intermediário parasita: apenas absorve os valores e as vantagens das outras indústrias, por si nada vle. Vive da marcha das indústrias. Destas escolas, nem uma nem outra têm razão em negar ao comércio valor produtivo. Produzir não quer dizer transformar a matéria prima, como pretendem os socialistas. Na indústria extrativa, o homem não transforma os produtos naturais, e ela produz. Não se fala em transformar o valor pròpriamente objetivo, mas numa transformação subjetiva. De que vale para o consumidor que haja nos mercados distantes as cousas que êle precisa? De que serviria para nós o chá da India, se êsse chá, a não ser possível transportá-lo, não teria absolutamente valor. O consumidor, que vai aos mercados de produção buscar os produtos para pô-los à disposição nos mercados de consumo à proporção que o consumidor precisa dêles. incontestàvelmente dá mais valor a êsse objeto, a essa utilidade que deve ser adaptada às necessidades do homem.

\section{II}

Noção do comércio; seus elementos econômico e jurídico. Função orgânica do comércio.

A palavra comércio tem vários acepções ou sentidos diferentes, conforme o ponto de vista sob o qual se considera. Demais, não é possível dar uma definição verdadei- 
ra. uma definição lógica do que seja ela. Definir uma cousa é delimitar, circunscrever o que pretende definir e estudar, explicar a natureza dessa mesma cousa, determinar o que essa cousa é. É preciso, portanto, reunir os elementos e as propriedades essenciais dessa cousa, armar esta reunião em uma fórmula geral e constituir a definição. Não é possível estabelecer uma definição precisa do que seja comércio porque ainda se não conseguiu estabelecer a verdadeira relação dos elementos que o constituem.

A palavra comércio vem do latim commercium, resultante da contração de duas palavras distintas: - cum e merx. Cum determina tempo, ligação, continuidade, simultaneidade de uma cousa; merx significa vitualhas, víveres, mercadorias, gêneros, fazendas. Na própria língua latina se encontra a palavra commercium com a significacão de merx. Há ainda outra expressão adequada, significando o sentido jurídico oú econômico da palavra - é trato, tráfego, tráfico, donde vêm as expressões tratante e traficante que, no antigo Direito português, significavam. não o que significam hoje: chatim, homem que nem lisa nem honestamente faz as operações comerciais, mas o que honesta e lisamente intervinha em tais operações. A palavra negócio, vinda de nec e otium é outra acepção.. Desta palavra se deriva o adjetivo negociante que muitas acepções tem na técnica de nossas leis e que mais se usava no antigo Direito português, em que se não encontra o têrmo comerciante. $\mathrm{O}$ nosso Código Comercial emprega mais a palavra mercancia, que significa arte, trato de comerciar, e tem como cognatas: mercar, mercantilizar, mercantil.

Além dessa significação etimológica, há a usual, que não deve ser confundida com a expressão técnica de comércio. Tanto no nosso Direito, como no romano, a palavra comércio, além do significado técnico, próprio, tinha, para significar o fenômeno jurídico do comércio. a acepção chamada usual. 
Na legislação romana a palavra comércio podia referir-se às pessôas ou às cousas, e, por isso, podia ser tomada em sentido subjetivo ou objetivo. No sentido subjetivo se referia à investidura, à capacidade que tinha o cidadão romano de poder entrar como parte em certos contratos de Direito Civil, para os quais a lei exigia modo solene na celebração desses contratos. Era direito exclusivo do cidadão romano, jus modi civilibus, pois só êle podia ter o jus comercii, e é nêste sentido que Ulpiano diz; De regulis, tit. 19, $\S 4$ : commercium est emendi vendedique invicem jus, é o direito recíproco de compra e venda. No sentido objetivo, o comércio se referia aos bens, que se dividiam em: res in commercio e res extra commercium, cousas que estão no comércio e que estão fora dêle. Aquêles podiam. ser alienados e êstes de forma alguma podiam fazer parte do patrimônio particular, bens públicos, como, entre nós, os estaduais ou federais. O nosso Direito adota uma tal distinção, significando cousas no comércio as que têm. capacidade para serem apropriadas, e significando cousas fora do comércio as que não são suscetiveis de apropriação. No nosso Díreito, tratando o legislador de determinar a penhora comercial, fazendo a relação de várias cousas. que não podem ser suscetíveis de penhora, estabeleceu, no art. 529 do Decr. n. 737 de 25 de novembro de 1850, não poder a penhora recair sôbre cousas extra commercium. A lei, por disposição expressa, exclui estas cousas da suscetibilidade de serem apropriadas, colocando-as fora de comércio. Ainda por uma disposição de última vontade, as cousas se podem tornar inalienáveis.

Em acepção figurada, a palavra comércio significa o direito de comunỉcação, as relações sociais entre os homens : o comércio das letras, o comércio das musas. sim que diz TÁcito: commercium sortis humanae. Também pode referir-se às relações com Deus : celeste commercium, commercium admirabile, diz Scaccia; ou às cousas da guerra: belli commercia, como diz Virgílio, ou como diz 
TÁcito: commercia belli derimere. Ainda, na sua acepção figurada, pode ser tomada a palavra no sentido de uso, exercício de uma cousa: commercium non pudam linguae Ansoniae, diz Ovíblo.

Na ordem cronológica dos fenỗmenos sociais, o comércio se apresenta, primeiramente, como um fenômeno econômico, uma manifestação econômica de tôdas as sociedades, mesmo as mais rudimentares e as mais grosseiramente organizadas. Dêsde o primeiro momento de sua existência, o homem foi sempre estimulado por necessidades de ordem física e de ordem intelectual, necessidades contínuas que crescem na razão direta do maior grau de civilização do meio em que o homem vive. Pelo próprio instinto da conservação, é claro que o homem, tendo necessidades, precisava dos meios adequados para a sua satisfação, o que êle consegue apropriando-se dos meios que os economistas chamam utilidades e que são oferecidos pela natureza exterior. Essas utilidades, porém, só podem ser aproveitadas, umas, pela sua transformação, e outras pela sua adaptação. A caça, a pesca, os frutos com que o homem satisfazia às primeiras necessidades da alimentação, precisavam ser apropriados, e uma tal apropriação só se conseguia por meio de um esfôrço, que, sendo útil, é conhecido sob o nome de trabalho pela Economia Política. Entretanto, devido a causas muito complexas e variadas. desde a conhecida imperfeição da produtividade do solo nas diferentes regiões, às diferenças de clima e tantas outras cousas, o homem, só por si, seria incapaz de satisfazer a todas às suas necessidades, mesmo às mais elementares. Desde que abrimos os olhos à luz matutina, até que os cerramos ao sono da noite, continuamente utilizamos os esforços dos nossos semelhantes repartidos pelas mais remotas regiões do globo, embora por nossa vez produzamos, e o nosso trabalho seja aproveitado por outros indivíduos da comunhão social. A especialização das funções e do trabalho. faz um homem produzir mais do que o que possa precisar, e, então, surge 
a primeira troca ou escambo da produção superabundante do produtor, determinando uma circulação de bens, de. utilidades, de mercadorias. A utilidade de uma mercadoria é determinada pela possibilidade de ser ela aproveitada. De modo que o produtor, um agricultor, por exemplo, não teria outro interêsse senão produzir tantos cereais quantos fossem necessários para o seu sustento e para o de sua família. Mas como a terra é fértil e recompensa o seu esfôrço com uma colheita superior às suas necessidades, e como nem todos os homens podem ser agricultores, resulta que o excesso na produção do agricultor adquire para os homens que não são agricultores, utilidade que cresce na razão direta em que crescem ou se desenvolvem as necessidades que se destina fazer. Eis aí a noção primordial do comércio, econômicamente considerado.

Nem sempre reinou inteira harmonia de vistas entre os escritores, quanto ao modo pelo qual se desenvolvem as funções econômicas do comércio, o que, aliás, não deve causar estranheza, porque a sistematizaçã̉o dos princípios que regem os fenômenos econômicos é de data recentíssima. Acresce ainda que a atividade circulante do comércio, que observamos hoje nos grandes centros mercantís, tomou uma marcha vertiginosa com os seus variadíssimos e eficazes instrumentos de ação. Os transportes, hoje, fizeram desaparecer as distâncias. Não mais existe a diversidade das produções segundo as várias regiões do globo, pois a cada um de nós é dado consumir os produtos originários de regiões antípodas da nossa. A moeda, a medida universal do valor, a troca de mercadorias em espécie, tornou-se por demais pesada para certos negócios e foi substituida pelo crédito com os seus admiráveis meios: as contas-correntes, a letra de câmbio, etc.

Os maiores mestres de Direito Comercial, como os chama o notável Vidari - Stracca e Scaccia, tinham uma nocão errônea do comércio. Para Stracca (mercatura est officium quod, ratione quaestus liciti, exercetur in permu- 
tandis emendisque frequenter mercibus, quoque non mutata per se forma) o comércio consistia no ofício de permutar e comprar frequentemente as mercadorias, tendo em vista o lucro lícito, mas sòmente enquanto essa mercadoria não tivesse a sua forma mudada. Em caso contrário, teríamos diante de nós a indústria manufatureira. Nas mesmas idéias se inspirou o comercialista clássico Scaccia (negotiatio sea mercatura, id est, negotiador seu mercator, quando rem, quam causa lucrandi emit, postea immutata forma revendit, dicitur proprie negotiatio seu mercatura), para quem só pode haver comércio e, portanto, comerciante, quando se revende uma cousa comprada com o fim de lucro, mas sem que se the mudasse a sua forma. E, para tornar bem clara a sua idéia, Scaccia exemplifica: aquêle que compra vime, para, entretecendo uma cesta, vendê-lo por esta forma, não pratica o comércio, é um simples artífice, assim como artífice é o que compra o fio para fazer redes, lã para tecer pano, da mesma forma que não è comerciante, mas mecânico, aquêle que compra ferro bruto para revendê-lo em obra.

E o lucro já aparece influenciando as operações mercantís; e a necessidade de frequência das operações, sem a qual as operações de compra e venda, ou mesmo a permuta, quando isoladas, não podem ser consideradas de comércio, mas simples contratos de natureza civil, também começa de aparecer. Mas nem é exclusivamente por meio da compra para revender ou por meio da permuta que se manifesta o fato econômico do comércio, nem podem ser excluidos do número dos comerciantes aquêles que Scaccia denomina: artífices ou mecânicos. $O$ transporte, o câmbio, o depósito, a conta-corrente, são tantas operações perfeitamente caracterizadas como operações comerciais, sem serem compra, venda ou permuta. Ademais, as disposições das legislações dos diferentes povos e a doutrina têm sempre considerado na classe dos comerciantes, sob certas condições, o tecelão, o ourives, o mecânico. 
Em suas mëditações sôbre a Economia Política, outro escritor italiano, VERRI, deixando-se impressionar com o fato de que a atividade mercantil se manifesta mais frequentemente pelo transporte, pela aproximação entre o produtor e o consumidor, separados por grandes distâncias, considerou como feição característica do comércio o transporte das mercadorias de um lugar para outro. Mas não é exclusivamente pelo transporte das mercadorias que se manifesta a atividade econômica do comércio. Mercadorias depositadas num armazém podem ser vendidas e revendidas um sem números de vezes. $E$ ninguém deixará de afirmar que essas permutas, vendas e revendas constituem operações comerciais.

Umas e outras das opiniões expostas tomam a parte pelo todo, quando êsses dois elementos diferentes têm importância igual.

Mais feliz, Romagnosi asseverou que o comerciante é intermediário entre o produtor e o consumidor, lamentando-se, todavia, que, quando trata de dar a noção econômica do comércio, não tenha desenvolvido a sua noção fundamental, que era exata, e tivesse feito repousar o traço diferencial do comércio na troca das cousas livremente dadas e aceitas a mútuo aprazimento das partes. Um exemplo bastará para demonstrar o êrro da definição de Romagnosi: si um vinhateiro vende uva a uma pessôa para fabricar vinho para seu uso pessoal, evidentemente aí se encontra a permuta de cousas reputadas úteis peals duas partes contratantes. Ninguém, entanto, suistentará existir aí uma manifestação de comércio: não é ato de comércio para o vinhateiro, porque êle não pratica mais do que a indústria agrícola e não é ato de comércio para o comprador da uva, porque êle pratica um ato de mero consumo individual.

Definindo comércio, Massé, notável escritor, dos de mais renome na França contemporânea, diz que êle é o complexo de negociações que tem por escôpo operar e facilitar a troca dos produtos naturais ou industriais, com o fim det 
auferir algum proveito. Quando as relações de interêsse entre os homens, continua, tem lugar frequente e assiduamente, temos aí o verdadeiro comércio, econômicamente considerado. E acrescenta: o comércio é uma especulação onde se compra para revender, e onde se vende aquilo que se comprou para revender, não se devendo daí concluir, adverte cautelosamente, que só haja comércio quando existir uma compra para revender. Nesta operação, nós desvendamos, observa ainda Massé, três classes de atos: que precedem o comércio, a compra e venda, grande número de atos e contratos que servem de acessórios à compra e venda comercial, outros atos que são consequências da mesma compra e venda característica do comércio, e outros ainda, que, sem serem do comércio, são um incentivo, um móvel acessório ou consequente da verdadeira função econômica do comércio.

A definição de MAssé representa já um passo para a aquisição da verdadeira noção econômica do comércio. Aí nós encontramos tôdas as operações capitais do comércio: a mediação frequente entre o consumo e a produção, a facilitação da troca dos produtos, quer naturais quer industriais, com o intuito de auferir lucro. E não faz questão da forma das mercadorias. Evita-se o inconveniente da definição dos antigos comercialistas, pois nesta, embora se abranja o transporte das mercadorias de uma região para outra (e compreende-se que, alcançando a definição todas as operações destinadas a efetuar a troca dos produtos, devesse incluir, portanto, o transporte), entretanto nessa expressão estão também compreendidas outras operações e atos, que, não sendo pròpriamente de deslocação material dos produtos, facilitam o problema da circulação das riquezas.

Mas uma objeção se levanta contra a definição de MASSÉ: o ter deixado como na penumbra o elemento do lucro, que também caracteriza o comércio, pois, nas operações comerciais, o lucro atua como elemento determinan- 
te, como causa eficiente, como causa única. Uma pessoa que compra um prédio para si, tem, certamente, em vista um proveito; pode, sob certo aspecto, praticar uma mediação entre a oferta e a procura, mas nesse proveito não se encontra o característico do comércio, porque êle não tem por causa única o lucro. A idéia do lucro é fundamental para a noção econômica do comércio. Na definição de MASsÉ falta relêvo a essa idéia substancial. A idéia do lucro é determinante, é o fim fundamental do comércio, e, como dizia o cardeal DE LucCa : finis mercatorum est lucrum. Si não fôsse êsse único defeito, a definição de Massé, no dizer de VIDARI, seria perfeitamente aceitável.

Debaixo dêste ponto de vista, mais correta seria a noção de Beslay, ao dizer que o comércio se caracteriza ou resulta de dois elementos: de um ato de intermediação entre a oferta e a procura, e do lucro, que deve servir de causa eficiente para o exercício dêsse ato.

De conformidade com as idéias manifestadas por BEsLAY estão os juristas e comercialistas alemães modernos, entre os quais Goldschmidt, Thöll $e$ Endemann. Entre as diversas definições encontradas nos tratadistas, há uma aceitável, nos seguintes têrmos: O comércio é uma função orgânica de mediação especulativa entre a oferta e a procura das mercadorias, preordenada à circulação econômica.

É uma definição perfeita, filosòficamente considerada, na qual se consegue caracterisar o objeto definido, já pelo gênero a que pertence, já pelo traço diferencial de suá espécie.

\section{Função orgânica.}

Assim como o corpo humano se compõe de orgãos essenciais para o seu desenvolvimento e para a sua vida normal, chamada pela ciência de vida fisiológica, assim também os corpos sociais têm orgãos por meio dos quais desenvolvem a sua vida normal, por meio dos quais con- 
seguem o seu destino e o seu fim. Diversos orgãos existem que traduzem o poder, e são os orgãos políticos que traduzem os fenômenos vitais da sociedade, como os poderes legislativo e judiciário com as suas diferentes ramificações. $\mathrm{E}$ ao lado dos orgãos políticos se encontram os orgãos econômicos, que servem para o desenvolvimento das fôrças econômicas duma nação, para a manutenção e engrandecimento da riqueza nacional nas suas diferentes espécies de manifestação. A produção econômica de um país, o consumo, a circulação das riquezas, o trabalho, os valores, o crédito, constituem os problemas que interessam de perto à vida econômica e ao engrandecimento financeiro. E tanto assim é, que se observa que sòmente são verdadeiramente poderosos, econômicamente falando, aquêles paises onde se observam os preceitos da Economia Política. A circulação das riquezas em uma nação pode ser, com a maior propriedade, comparada à circulação do sangue no corpo humano. A Economia Política, quando denominou circulação ao movimento dos bens e riquezas numa nação, foi buscar o têrmo à própria ciễncía da medicina, pela analogia que encontrou entre os dois fenômenos. Desde o momento em que a circulação do sangue se faz regularmente e de acôrdo com a vida fisiológica, e não há excesso nem falha nessa circulação, não é difícil prognosticar que se trata de um corpo são; assim também, se no corpo social a circulação das riquezas é motivada por uma produção regular e inteligente, pode-se afirmar que a vida econômica dessa nação é regular, encontrando-se uma nação econômicamente sã. Os corpos sociais, politicamente organizados, vivem vida política, assim como vivem vida científica ou vida econômica. Onde há vida, fatalmente devem existir orgãos, e, portanto, funções orgânicas. E, se existem funções orgânicas econômicas na vida das nações, é indiscutivelmente o comércio, que se interpõe entre a produção e o consumos promovendo a circulação das riquezas. Sem o comércio, a produção se estiolaria e teria de limitar-se ao consumo 
local, talvez inferior a si própria; o consumo sofreria várias privações de produtos que não são originários da produção local; não haveria circulação das riquezas. Um corpo onde não circula o sangue é um corpo morto. $O$ comércio é, portantơ, uma função orgânica, vital, de tal importância, que vem melhorar todas as outras condições da vida social.

\section{Mediação especulativa.}

Outras funções orgânicas existem que não são mercantís. A produção, debaixo do ponto de vista exclusivamente econômico; o consumo, considerado de per si; o valor; a moeda e tantos outros institutos econômicos, servem para o exercício de funções orgânicas, mas não fazem parte do domínio do comércio. É mistér determinar em que consiste a função orgânica do comércio, e daí o dizer a definição que o comércio só é tal, quando a função orgânica se opera pela mediação especulativa. Sempre, em qualquer de suas manifestações, o conıércio há de ter a função de mediador que se interpõe entre a oferta e a procura das mercadorias.

Poder-se-á objetar contra a definição que ela tem uma falha, e, de fato, bastará, dirão, demonstrar que o comerciante, indo buscar as mercadorias às fontes de produção, e trazendo-as até colocá-las ao alcance do consumidor, ou mesmo indo comprar grandes provisões de mercadorias para depois revendê-las em pequenas porções proporcionais às necessidades individuais de cada consumidor, aumenta o valor dessa mercadoria. O falo é fácil de observar, pois nas fontes de produção o negociante paga um preço inferior àquele que lhe paga o consumidor, e nisto consiste o Iucro do negociante. De modo que, trazendo o comércio como consequência um aumento no valor da mercadoria, poder-se-ia dizer que a definição é falha por deixar de mencionar essa circunstância. A censura, entretanto, não seria justa, porque o aumento do valor, que é indiscutível, 
não é mais do que uma consequência natural da própria mediação, que se destina justamente a conseguí-lo.

$E$ digamos porque a definição diz mediação especulativa e não lucrativa, quando êste têrmo parece traduzir com mais exatidão a idéia do lucro que deve predominar no comércio. O lucro do comércio não é toda e qualquer vantagem que conseguimos, todo e qualquer aumento do valor, e sim, como ensina Vidari, o proveito que é determinado, é medido pela circulação dos valores, levando-se em conta as condições de lugar e tempo, de oferta e de procura, dentro das quais se desenvolve a circulação econômica. Um particular, por exemplo, acionista duma sociedade anônima, que vende as suas ações porque elas atingiram um preço superior àquele que êle pagou, tem em vista um proveito, um lucro, que não é verdadeiramente comercial porque destinado a satisfazer às necessidades individuais dêsse acionista, ao passo que, no comércio, o lucro do comerciante não é destinado a satisfazer às suas necessidades individuais, mas é condição para que êle possa prosseguir no exercício regular do seu comércio. A especulação própria do comércio é aquela que tem como causa eficiente a circulação dos valores destinados à reprodução do lucro ou proveito mercantil que provém dêsse ato. $\mathrm{E}$, para a especulação mercantil, basta que a operação seja destinada a deixar lucro; basta que a intenção do comerciante seja de lucrar, e nem outra pode ser, porque não seria para ter prejuizo que empregaria seus capitais; basta que exista a operação comercial para que haja uma fartíssima presunção de que visa o lucro, pois o comércio é destinado, por sua natureza, a deixar lucro. E êsse lucro não precisa ser imediato. Diàriamente se vêem à venda produtos ao preço da compra, e até por preço inferior: são os artigos de reclamo, que visem atrair a clientela aos armazéns, e destinados a deixar ao comerciante um lucro remoto em outras. mercadorias. 
A mediação precisa ser exercida frequentemente ou de um modo habitual pelo comerciante, pois no caso de uma compra para revenda isolada. haverá um simples contrato de ordem civil. A nossa definição evidencia perfeitamente um tal elemento quando diz ser o comércio uma funçôo orgànica: não se compreende função orgânica que se exercite de tempos a tempos; ela deve ser regular, contínua, habitual.

\section{Entre a oferta e a procura.}

Conhecido o que seja produção e consumo, desnecessário é explicar o que seja oferta e procura: são têrmos que se equivalem. A mediação não importa sempre na deslocação material das mercadorias; pode dar-se mesmo em relação a mercadorias que estejam nos armazéns gerais, onde são representadas por warrants, pápeis representativos da mercadoria, títulos que podem ser transferidos por. simples declaração escrita no seu verso - o que se chama endôsso, e que tem como efeito a transferência da propriedade da mercadoria. As cousas que estão fora do comércio não podem ser objeto de transações mercantís.

\section{Das mercadorias.}

Mercadoria é uma espécie do gênero cousa. Cousa, econômicamente falando, é tudo aquilo que tem um valor de troca, que é útil e permutável. Mas esta utilidade e permutabilidade, para caraterizar a cousa econômicamente, deve concorrer concomitantemente com o objeto, o que quer dizer que existe muita cousa que è útil: o calor do sol, e que. entretanto, não é permutável. assim como cousas existem que são permutáveis e que por vêzes deixam de ser uteis. Exemplo típico é o do viajante que encontrasse, morto de fome. num deserto, uma bolsa cheia de pérolas. Tôda a mercadoria é uma cousa. e nem tôda a cousa é mercadoria. A diferença entre cousa e mercadoria, no dizer 
dum escritor alemão, é mais uma diferença de modo que de substância. As cousas destinadas à circulação econômica adquirem a qualidad̉e de mercadorias, são cousas que estão à venda. Mercadorias, pois, são as cousas sôbre as quais a pessoa, singular ou coletiva, pode concitar a sua atividade comercial. diretamente ou por meio de agentes. Para o nosso Código Comercial e para outras legislações, existe ainda um requisito da mercadoria: que se trate de cousas móveis. Esse modo de ver. entretanto, vai cedendo terreno, e o novo Código Italiano considera como mercadorias os imóveis, sob certas condições.

\section{Preordenada à circulação econômica.}

Explicando o modo pelo qual o comércio consegue realizar a circulação econômica das mercadorias, Thaller diz que o fim do comércio, considerado sob um ponto de vista mais geral, consiste em levar a mercadoria desde sua fonte de produção até a sua última estação de consumo, quer para ser transformada, quer para ser entregue ao mercado. Daí resulta trazer o comércio consigo a idéia de movimento, que se pode operar até dentro do próprio mercado onde se acham as mercadorias. Entre o produtor e o consumidor estabelece-se uma longa série de agentes intermediários destinados todos a pôr a mercadoria ao alcance do consumidor. Outras vêzes não há a deslocação material das mercadorias e. entretanto, há a circulação econômica. Às vezes um determinado gênero de comércio ou títulos de crédito, no mesmo dia. sofrem diferentes oscilações, que representam precisamente a circulação econômica em virtude da lei da oferta e da procura. Suponhamos os títulos de crédito de uma sociedade anônima cujo capital fôsse representado por cem mil ações: uma simples oscilação de mil réis em cada ação representará uma diferença de cotação de cem contos de réis em relação ao valor do mesmo capital. Isto vem demonstrar como se opera a 
circulação econômica dos valores, circulação essa determinada pela lei da oferta e da procura. E de fato, desde o momento que uma mercadoria ou um papel de crédito suba de cotação, é natural que o seu possuidor dela se desfaça, visto como êle ufere lucro, e inversamente se êle baixa. Por isso é que ScHäfle, economista alemão, dizia que a circulação no corpo social é uma parte integrante do todo orgânico do mesmo corpo social.

É difícil, senão impossível, dar uma definição perfeita do comércio. Entre os economistas e comercialistas encontram-se três classes de definições ou de noções, umas levando apenas em consideração o elemento econômico do comércio, outras apenas o elemento jurídico e outras harmonizando, reunindo êsses dois elementos para formar a definição que êles entendem ser aceitável. Entre os economistas não se encontra definição alguma aceitável que determine as propriedades essenciais ou as propriedades substanciais do comércio, econômicamente falando; umas definições são muito vagas, muito amplas, e outras muito restritas. Entre as primeiras nota-se a de LERoY-BeAulied, e essa mesma definição, mais ou menos, encontra-se em, Say, Bianchini e outros, que, em vez de dizerem que o comércio é a sistematização das trocas, dizem que é a indústria das trocas. Mas a troca não se pode confundir com o comércio: faltam-lhe os elementos, a coordenação, as propriedades essenciais do comércio, que não se pode dizer que seja uma troca sistematizada ou uma troca industrial. Outros restringem esta noção. Ferreira Borges diz quie o comércio, econômicamente falando, é a compra $e$ venda das mercadorias; GeNovesi, que é a troca do supérfluo pelo necessário, e Galliani, que è a simples comunhão de trabalho para satisfazer as necessidades do homem. Estas definições são restritas; compreende-se perfeitamente que o comércio, econômicamente falando, não se resume na comunicação pelo trabalho; o trabalho é um simples fator da produção. Não se resume também nos contratos de 
compra e venda, porque, embora os contratos de compra e venda sejam mais comuns, nãó são a única manifestação do comércio.

É opinião corrente entre os economistas que a troca equivale ao comércio. A maioria das trocas, entretanto, não pode ser comércio. A troca è o fato fundamental do comércio. O comércio é uma evolução da troca. De acôrdo com êsses princípios, pode-se dizer que, em Economia Política o comércio é a troca por meio da mediação. Dessas definições resulta que o elemento econômico é simplesmente a mediação, a intromissão, a intervenção entre a produção e o consumo.

Vejamos o elemento jurídico.

Entre os comercialistas que tratam de definir ou de dar uma noção do comércio, uns generalizam por demais éssa noção. Em Stracca, com efeito, se vê que êle entendia a palavra comércio como sinônimo de todo e qualquer contrato: verbum commercium generale est ad omnem contratum. A mesma cousa dizia Goldschmidt afirmando que o comércio é a mediação na circulação. 0 mesmo defeito se encontra em EndEMANN, quando diz que o comércio é o movimento dos bens na circulação. São noções muito vagas. Entre os que mais as generalizam, encontra-se Thaller dizendo que o comércio è a circulaçâa dos produtos, dinheiros, títulos fiduciários, de modo que o comércio abrange tudo quanto diz respeito à cỉrculação, não só manifestada pela troca como pelo transporte.

Outros comercialistas restringem demasiadamente a noção do elemento jurídico do comércio. Stracca define o comércio como sendo um ofício - mercatura est officium. - - movido pelo lucro, pela especulação, exerce-se na permuta, compra e venda das mercadorias. O mesmo defeito se encontra na definição de Scaccia, que restringe o comércio às compras causa lucrandi, à compra e venda. Mas destas duas ordens de noções, amplas ou restritas, pode-se ver já que o elemento jurídico do comércio como 
que se pronuncia no lucro. Na definição de Stracca, por exemplo, êle se exerce ratione quaestus liciti, pelo motivo do lucro, por motivo de tirar vantagens, de auferir proveitos ou lucros lícitos. Exatamente no fito de lucrar, de ganhar, de especular é que reside a noção jurídica do comércio.

Êstes dois elementos é que devem formar, devem convergir para compor a noção ou definição do comércio, com tôdas as propriedades, todos os organismos diferentes, o organismo econômico fornecendo a mediação e o organismo jurídico fornecendo o fito de lucro ou a especulação.

Outros abandonam por completo a idéia de dar uma noção ou definição do comércio; entendem que é dificílimo compor uma definição exata das operações do comércio sob um aspeto geral para determinar precisamente o elemento substancial, as propriedades indispensáveis do comércio. Dentre êses destaca-se Lyon CAEN, que, não obstante, diz que o comércio é um conjunto de operações feitas com o fito de lucro para transformar, transportar $e$ trocar a matéria prima.

Outros, por absoluto, renunciam à idéia de definir o comércio, e, em geral, pertencem à escola inovadora de D. Comercial a cuja frente se encontra Vrvante. Nem a lei e nem a doutrina oferecem um critério seguro para constituir a definição.

Não se podendo dar uma definição concisa, recíproca e clara, que a lógica aceita, entenderam alguns economistas poder dar uma definiçâo descritiva do que seja comércio. Vidari diz que o comércio $e^{\prime}$ um complexo de atos de mediação entre a produção e o consumo, exercitados habitualmente com o fim do lucro e com o fim de aumentar a circulação das riquezas, tornando mais fácil e cômoda a procura $e$ a oferta. Constans diz que o comércio é êsse ramo da atividade que tem por objeto aproximar a produção e o consumo pela troca em tempo e lugar e em qualidade e quantidade convenientes. 
Outros, como Supino, Germano, Franchi, Branccacio, procuram resumir ou reduzir essa noção descritiva a uma noção lógica. SuprNo diz que o comércio é a indústria que, com o fito de lucro, se interpõe entre a produçâo e o consumo para promover e aumentar a circulação das riquezas. Germano também assim se exprime: o comércio é um complexo de mediações que operam e facilitam a troca com $。$ fito do lucro. E Branccacio diz que o comércio é a mediação entre a produção e o consumo com o fito de especular. Esta definição foi perfilhada, no direito pátrio, pelo conselheiro Silva Costa, em seu magnifico Tratado de Direito Comercial Maritimo.

Não aceitamos nenhuma dessa definições. O comércio tem por fim fundamental a troca, e a troca é uma das manifestações da especulação. A circulação resulta da série de movimentos entre a produção e o consumo. Esta série de movimentos não pode ser de atos isolados, de atos entre si independentes; será ao contrário, de atos coordenados, que têm uma certa sequência, uma certa ordem; êsses atos não podem ser praticados a êsmo, devem obedecer a um vínculo comum. É preciso, pois, quando se trata de definir o que seja comércio, primar em mostrar a sequência dos atos que entre si são travados, ligados, e em determinar perfeitamente esta coordenação, que tem entre si os atos de comércio, dependentes um dos outros, de modo que são verdadeiros elos duma corrente interminável. É preciso encontrar um têrmo que manifeste perfeitamente esta coordenação, esta ligação, êste organismo que tem os atos do comércio. $E$, à procura dêle, encontramos a maior variedade possivel de definições dadas pelos comercialistas. Uns dizem que o ato do comércio é um complexo. Complexo é uma reunião de cousas ligadas por um vínculo. Dentre êstes, pode-se citar: Vidari, que diz que o comércio é um complexo de atos; Marchieri, que diz um complexo de fatos; Bolafio que o considera 
um complexo d'e operações, e ETENA, que o define como um complexo de trocas ou mediações.

Outros põem de parte o têrmo compiexo e usam do têrmo conjunto. Êste têrmo melhor esclarece. A expressão conjunto quer dizer que as partes componentes dêsse todo desaparecem para se manifestar a totalidade, todo o conjunto dessa cousa. Usam dessa expressão TorTori, que diz o comércio um conjunto de relações; Lyon CAEN, que fala de um conjunto de operações. Outros, como MAssÉ e PARdessus, usam da expressão complexo de negociações, e outros, como Molinier e Rivière, usam da expressão complexo, ou seja de operações ou de negociações.

Pondo de parte êstes têrmos complexo e conjunto, que entram nessas definições, entendem alguns comercialistas que se pode frizar esta relação usando da expressão série. Assim é que se encontra o comércio considerado como uma série de operações ou de negociações. Mais aproximados da verdade, porém, estão aqueles que usam de outra expressão, desprezando essas primeiras, para determinar o nexo, o vínculo, a conexão dos atos do comércio. Em Goldschmidt, em Branccacio, em Endemann, em Stracca, em B. Say, em Supino, em Boccardo e outros, encontram-se as expressões: mediação, atividade, oficio, indústria.

Muito embora estas denominações sejam menos impróprias do que as denominações de complexo e de conjunto ou de série para determinar o organismo dos atos do comércio, entretanto deve-se preferir aquela a que se refere: o programa: mais do que tudo isso, o comércio é uma função orgânica. Função é uma ação dependente ou manifestada por orgãos de conformidade com a natureza e fins dêsses mesmos orgãos. E, quando se diz função orgânica, quer-se dizer que esta função é inerente, é jntrínseca a êsse mesmo fim. De modo que se pode dizer que o comércio é uma função orgânica, e por essa palavra os atos: de comércio se apresentam perfeitamente, claramente coordenados pela sequência que devem guardar entre si, de maneira que uns são consequentes dos outros, uns explicam 
os outros, são atos perfeitamente travados, atos perfeitamente industriais de uma série para indicar perfeitamente essa sequência, êsse vínculo que têm entre si os atos do comércio.

Vejamos como se manifesta essa função orgânica.

Com relação a êste ponto também divergem muito os comercialistas. Assim, uns dizem que o comércio é manifestado pela troca, é uma permula, como quer Verri; é uma troca do supérfluo pelo necessário, como dizia GENovESI; é uma troca do útil pelo menos útil, como exprime Beccaria. Oulıos, porém, usam do lêrmo circulação dos produtos, como Thallen; outros da expressão indústria que põe da disposição do consumilar os objetos de que êle necessita, como por exemplo João Baptista SAY. Mas êstes elementos não podem servir para formar a definição ou para operar a coordenação dessa definição. Esta função orgânica se manifesta por meio da mediação, por meio da intervenção, por meio da intromissão entre a oferta e a procura, ou mais remotamente entre a produção e o consumo. É por meio da mediação, por meio da intervenção, por meio da intromissão entre a oferta e a procura, que se manifesta, que se torna precisa e clara esta função orgânica do comércio. Mas esta função orgânica de mediação dever ter um móvel para a sua ação; êsse móvel se chama lucro, proveito, vantagem. Não é um lucro, um benefício, no sentido geral que é o elemento primordial que exprime a necessidade da mediação no comércio. O lucro, a que chamamos especulação, como elemento jurídico, quer dizer: evento de lucro 'u dano. Os comerciantes, quando compram as mercadorias nos mercados de produção, jogam sôbre a diferença do preço, e por isso muitas vezes perdem. Muitas vezes o comerciante vê-se obrigado a vender as suas mercadorias pelo preço da compra; entretanto, apesar dêle não ter êste lucro, não ter esta vantagem efetiva, nem por isso deixa de ser um comerciante. A especulação é o nexo que liga a função orgânica à mediação, e êste nexo não se. encontra nos outros atos da vida civil, nos atos da vida 
comum. O comércio é, pois, uma função orgânica de mediação especulativa.

Mas quem diz mediação refere-se a dois têrmos opostos. E preciso determinar entre que têrmos ela se estabelece. Alguns comercialistas entendem que essa mediação se estabelece entre a produção e o consumo; quer dizer que se referem ao elemento primordial da troca, em que o indivídúo, dos mercados de produção, leva para os de consumo os objetos necessários para as necessidades humanas. Os têrmos produção e consumo são muito amplos, muito afastados desta mediação; é preciso dizer antes que é uma mediação especulativa entre a oferta e a procura. Mas sôbre que recaem a oferta e a procura? Uns dizem que a oferta e a procura recaem sôbre os bens em geral; outros dizem sôbre os bens econômicos, outros sôbre a matéria prima e outros sôbre a troca. Entretanto, convém, uma vez que se trata de encontrar uma noção precisa, usar do têrmo próprich, do têrmo técnico do que, em Economia Política, se chama utilidade, e é mercadoria. Mercadorias são tôdas aquelas utilidades econômicas, são tôdas aquelas vantagens econômicas que servem para a satisfação das necessidades do homem. E, si temos em D. Comercial esta palavra técnica, devemos usá-la de preferência a qualquer outra expressão, muito embora sejam aceitáveis, com relação à Economia Política, outras expressões, como, por exemplo, bens econômicos, riquezas, utilidades. Esta mediação especulativa entre a oferta e a procura deve recair sôbre as mercadorias, que correspondem aos bens econômicos, riquezas, utilidades.

Mas de que modo age, ou para que fim age o ato de comércio? Para que fim se exige do comerciante êsse ato de comércio, ou de que modo se exige do comerciante? Pela definição há pouco apontada de Vidari, os atos de comércio têm uma tríplice fim: efetuar, facilitar e promover a circulação das riquezas; outros dizem, como Supino, que os atos de comércio apenas operam e facilitam a circulação das riquezas. O comércio ảeve, não há dúvida 
nenhuma, efetuar, promover, facilitar a troca, a circulação econômica, mas nós podemos encontrar um têrmo que abranja tôdas estas modalidades do exercício do comércio, dizendo, por exemplo, que esta mediação, esta função orgânica é preordenada, predisposta à circulação dos bens.

Em vez de dizer que os atos de comércio promovem ou aumentam a circulação, podemos dizer que essa circulação, essa função orgânica é preordenada e predisposta para êsse fim. Mas preordenada ou predisposta, a que fim? Em Economia Política distinguem-se as indústrias pelo modo porque removem os obstáculos, as dificuldades. A indústria de transporte remove a dificuldade da distância entre os mercados de produção e os de consumo; a indústria da troca remove a dificuldade que havia de o consumidor ter necessidade de ir aos mercados de produção para aí se prover das utilidades de que êle necessitava para suas próprias necessidades; mas no D. Comercial estas duas indústrias se confundem debaixo da mesma relação jurídica. O D. Comercial tanto domina as relações provenientes pròpriamente da transmissão ou troca como as provenientes do transporte das mercadorias. Dizer, portanto, que esta função orgânica é preordenada, não tanto à troca, como à circulação das riquezas, é abranger, como bem se vê, todas as relações jurídicas no domínio do $D$. Comercial.

Justificados assim cada um dêstes têrmos, pode-se dizer que a definição mais aceitável no direito clássico é a que tem os dois elementos, o elemento econômico, que é a mediação, e o elemento jurídico, que é a especulação, ambas sendo preordenadas à circulação das riquezas. 
III

Ato de comércio ou mercancia. Teorias que tentam caraterizá-lo. Elementos componentes, consoante a opinião comumente recebida na escola clássica: mediação e especulação.

Antigamente não se encontrava distinção entre os atos de comércio prōpriamente ditos $\mathrm{e}$ os atos da vida civil. Mais tarde os atos de comércio foram apenas considerados em suas relações subjetivas, isto é, em relação ao sujeito que os praticava: desde que o comerciante pertencesse a uma corporação dêsse ofício, dessa profissão, todos os atos que êle praticasse eram atos comerciais.

Que é o comércio? Que é ato de comércio? Quais os seus sinais reveladores? Por que se distingue a comercialidade de um ato? Em tôdas estas questões apresentam-se dificuldades, senão impossibilidades.

Que é um ato de comércio?

Ato de comércio é um ato juridico, e ato jurídico é a revelação da atividade do homem no criar, no modificar, no extinguir um direito. $\mathrm{O}$ ato jurídico é, como disse o Projeto de Código Civil Brasileiro, um ato lícito que tem por fim imediato adquirir, modificar, conservar $e$ criar direitos. Este ato lícito, êste ato jurídico, compõe-se de três elementos: a capacidade do agente, o objeto dêsse mesmo ato e a forma preestabelecida ou facultada pela lei, e que deve revestir êsse ato. $O$ ato jurídico, pois, é um ato lícito. Ora, os atos de comércio podem ser ilícitos porque dos atos ilícitos podem derivar-se obrigações e negociações comerciais. Bastam dois exemplos para comprovar êste asserto: - - Quando se trata de violar o privilégio de patente de invenção (Decr. de 14 de outubro de 1882), os atos praticados por aquêle que o viola são até punidos por lei; entretanto, daí se derivam negociações comerciais. $O$ indivíduo que abusa ou viola a firma alheia, firma reconhecida de acôrdo com o Decr. de 24 de outubro de 1890, pratica um 
ato ilícito, e dêle, entretanto, se derivam negociações e obrigações comerciais. Se o comércio é um ato lícito, não pode absolutamente abranger atos ilícitos; ora, os atos ilicitos fazem também parte das negociações comerciais; portanto não parece correta a expressão ato de comércio para caraterizar todos os atos que entram nas relações de Direito Comercial. Por isso é que alguns autores, em vez da expressão ato de comércio, usam da expressão fato de comércio, por poder êste ser lícito ou ilícito; si é um fato lícito, é um ato jurídico; si é um fato ilícito também dêle se derivam obrigaçôes comerciais: o fato ilícito é fonte de obrigações.

A denominação ato de comércio é igualmente aceita, quer na doutrina, quer nos códigos. é verdade quc os códigos modernos, quando tratam de relacionar aquêles diferentes atos que formam o conjunto do comércio, dizem: atos de comércio, atos comerciais. $\mathrm{O}$ nosso código não usa da expressão ato de comércio (1), mas emprega a expressão negócio de comércio (art. 18, tit. 1), ou as expressões: negociação de comércio, negociações mercantís, direitos e obrigações, fatos de D. Comercial (arts. 14 e 16, tit. único). A expressão técnica do nosso direito é mercancia, (art. 19 do Decr. de 5 de novembro de 1850). Assim, em relação aos códigos, não é uniforme a denominação do que comumente se chama - ato de comércio. Em relação à doutrina, porém, esta expressão é corrente.

É preciso também não confundir o que se chama em doutrina ato de comércio e a matéria comercial, que os comercialistas, na Alemanha, principalmente, costumam distinguir. No seu último trabalho sôbre o Direito Cobercial Alemão, Cosack usa distintamente da expressão matéria comercial para significar em globo todos os atos comerciais, lícitos ou ilícitos, ficando a denominação ato de comércio para aquêles atos juridicos que são praticados

(1) Entenda-se: usa, mas incidentemente. como no art. 30 do Código, e no art. $14, \S 3$ do Reg. 737 de 25 de novembro' de 1850. 
por comerciantes no exercício de sua profissão industrial. Vê-se, pois, que a denominação matéria comercial abrange os atos de comércio e mais outros atos que não pertencem a essa espécie, ao passo que o ato de comércio é sempre um ato lícito praticado pelo comerciante no exercício de sua profissão, comercial ou industrial.

Os atos de comércio distribuem-se em várias classes: assim, existem atos de comércio objetivo ou absolutos, segundo a classificação alemã, atos relativos, atos que são comerciais pela forma, atos que são acessórios aos outros atos verdadeiramente comerciais. Ora, quando se pretende dar uma noção do ato de comércio, pretender-se-á, por ventura, abranger todos êsses atos, objetivos, de simples relação, de simples forma comercial, de simples acessão?

A escola clássica entende que da natureza íntima dos atos de comércio se podem deduzir os elementos característicos para separá-los dos atos da vida civil; confessa que, quando dá a noção de ato de comércio, tem apenas em vista o ato objetivo do comércio. Quando se dá, pois, a noção do objeto do comércio, segundo a escola clássica, não se abrangem todos os atos de comércio, mas sòmente os atos objetivos, atos re ipsa, cuja comercialidade resulta da natureza íntima dêsse mesmo ato. A escola clássica não conseguiu, pois, dar uma noção geral, uma noção ampla que abranja todos os atos que são disciplinados pelo Direito Comercial. Para se ver que não tem razão a doutrina da escola clássica, quando pretende dar uma noção incompleta do que seja ato de comércio, lógico é reconhecer que é impossível superar as dificuldades que há em encontrar uma noção que abranja em seu âmbito todos os atos comerciais regulados pelo D. Mercantil. Essa dificuldade que a escola clássica encontra em dar uma noção do que seja ato de comércio, abrangendo os atos objetivos, acessórios e os atos cuja forma apenas é comercial, ainda se revela quando ela trata de definir o ato re ipsa, o ato objetivo. Os próprios comercialistas desta escola confessam a dificuldade, senão a impossibilidade, mesmo com relação ao 
ato objetivo de comércio, de dar uma noção aceitável. Lyon CAEN, tratando de dar um sistema científico sôbre os preceitos do Direito Comercial Francês, quando trata de fazer a discriminação dos atos de comércio, declara sem reserva que o legislador não seguiu um sistema científico, que não se deixou guiar por considerações científicas nem abstratas, e que a discriminação dos atos do D. Comercial Positivo Francês não obedece a um principio racional. Entre nós, Teixeira de Fritas, na elaboração do Projeto de Código Civil, declara que a discriminação dos atos de comércio e do civil é exorbitante, arbitrária, por não se encontrar um critério científico suficiente para se poderem separar ou isolar um dos outros atos. Valbrègue disse que o ato de comércio tem o seu caráter dominante na especulação, na intenção de lucro: entretanto êle é o primeiro a dizer que a intenção do lucro, o fito de especular é insuficiente quando a pessoa vende os produtos da sua lavoura, porque os atos praticados pelos lavradores, embora no instuito de lucrar, não constituem atos de comércio. Diz êle também que alguns entendem que o ato de comércio revela um direito transitório, recai sôbre as mercadorias em movimento, é um modo da circulação econômica, e, entretanto, entram na direção, nas regras que o Direito Comercial expende para disciplinar êsses mesmos atos. Diz, em terceiro lugar, que outros encontram o característico do ato de comércio na circulação dos produtos, e êle então observa que êste critério não pode ser aceito porque há circulação de produtos que não é disciplinada pelas regras de Direito Comercial.

O próprio Thaller declara que o ato de comércio, para êle, está em todo e qualquer ato que intervenha na circulação econômica; confessa, entretanto, que a sua noção é ampla demais, e, por conseguinte, abrange um campo demasiadamente maior do que aquêle em que se deve conter o Direito Comercial, o que importa, diz êle, em que essa noção não pode ser recebida, porque não se pode, em nocões amplas, abranger todos os elementos e todas as pro- 
priedades do objeto definido. Ora, a noção que êle apresenta é, com efeito, inaceitável. Diz êle que o ato de comércio é todo o ato de uma profissão que tenha por fito o lucro, mas, acrescenta, esta noção só pode ser recebida mediante três condições: não entrarem nela todos os atos provenientes dos ofïcios manuais, nem os atos derivados das profissões liberais e nem os atos derivados da cultura do solo, da agricultura, da indústria agrícola.

É, pois, difícil encontrar uma noção precisa do que seja ato de comércio, que revele a sua natureza íntima e reuna os elementos indispensáveis para com êles se poder discriminar os atos de comércio dos atos da vida civil. Porisso é que Benevides, no seu livro Dos Contratos Comerciais, declara que, no estado atual da ciência, ainda se não encontra um critério lógico para se poder fazer a discriminação dos elementos constitutivos dos atos da vida comercial e dos atos da vida civil.

Apezar disso, alguns comercialistas têm feito tentativas, infelizmente falhas, para indicar os sinais reveladores da natureza íntima do chamado ato objetivo do comércio. Borstel, por exemplo, declara que o sinal distintivo do ato de comércio está em ser êle um direito transitório, recair sôbre os fatos da circulação das riquezas ou mercadorias. Quando êle trata, entretanto, de dar a noção do que seja um ato de comérciu, diz que êste só o é tal para o agente que, como intermediário, especula sôbre o valor do objeto de contrato. Refere-se êle à relação subjetiva, isto é, do agente que opera sôbre o valor dêsse mesmo objeto, o que vale dizer que êle, para dar a noção do ato objetivo do comércio, leva em mira a sua relação subjetiva, isto é: do ato em relação ao agente que o pratica. Obarrio diz que o ato de comércio é uma negociação sôbre cousas móveis com o intuito de lucro. A limitação - cousas móveis - sôbre as quais deve recair o ato de comércio, é o principal defeito desta definição, e razão suficiente para se não poder aceitá-la, porquanto hoje, não só na doutrina como na própria legislação dos povos cultos, o ato de comércio pode recair 
sôbre objetos imóveis. Outros, como Vidari, BesLay, MAnara, Thöll, Berhend e outros comercialistas da escola clássica entendem que se deve procurar os elementos característicos do ato de comércio objetivo - no elemento de mediação e no de especulação. Outros entendem que o caraterístico distintivo do ato de comércio está apenas na. mediação; e outros ainda entendem, como RubEN de Couder, que êle está, não no elemento da mediação, mas no da especulação. CIPELLI, comercialista italiano, o primeiro que tentou organizar cientificamente um sistema de atos de comércio, disse que o ato objetivo de comércio depende de três elementos: em primeiro lugar, a especulação ou o. intento de lucro; em segundo lugar, é preciso que o ato de comércio recaia sôbre matéria hábil, e, em terceiro lugar, que haja eventualidade de licro ou prejuizo para o capital empregado na transação comercial. Lyon CAEN, confessando que na legislação comercial francêsa não se encontra um critério lógico aceitável para se poder fazer a discriminação dos atos de comércio, diz implicitamente que êsse ato não pode ser definido, o que equivale a afirmar que é inteiramente arbitrária a separação, a enumeração feita pelo código do que seja ato de comércio. Há, porém, outros escritores mais modernos, e entre êles Apperr, que tentaram ver si era possivel organizar uma noção, uma definição em que se pudesse abranger todos os atos comerciais, isto é, todos os atos comerciais objetivos, porque, em relação aos atos subjetivos, acessórios e de simples forma comercial, a própria escola clássica reconhece que é impossível dar uma noção, mesmo aproximativa.

APPERT declara que o ato de comércio pode resultar da combinação dêstes três elementos: primeiro, de uma intermediação entre a oferta e a procura das utilidades que servem para a satisfação das necessidades do homem; segundo, que esta mediação seja movida pela especulação, que haja intuito de lucro; terceiro, que esta mediação eespeculação recaiam exclusivamente sôbre bens móveis, excluindo, portanto, os bens imóveis. Ora, a mesma obser-- 
vação que acabamos de fazer sôbre a noção de OBARRIo, pode-se também fazer sôbre esta que êle declara, todavia, ser a mais aceitável, porque os atos de comércio recaem não sòmente sôbre os bens móveis, mas ainda sôbre os imóveis. Se APPERT diz que o ato de comércio exclui as negociações sôbre bens imóveis, não dá, porisso mesmo, uma noção ampla, que abranja os atos objetivos, os atos re ipsa de Direito Comercial.

Dessas noções se colige, pois, que - si uns entendem que o ato de comércio é apenas um direito transitório sôbre a circulação dos bens; si outros entendem que êle se restringe tão sòmente à mediação; si ainda outros entendem que êle é todo ato ou fato que envolve o movimento da circulação econômica - entretanto é certo que a maioria dos comercialistas da escola clássica entende que é do conjunto da mediação e da especulação que se devem retirar os lementos indispensáveis para se poder determinar e precisar o que seja um ato de comércio.

Que é, pois, mediação? Que é especulação?

A produção é a criação de uma utilidade, de uma riqueza indispensável para as necesidades humanas; o consumo é o extremo, é a adaptação, o emprêgo, a aplicação dessa riqueza às necessidades do homem. São, como diz APpert, os dois polos da circulação econômica dos produtos. É preciso, portanto, um vínculo que ligue êsses extremos. Todos os atos que pertencem à produção e todos os que pertencem ao consumo não são considerados como atos de comércio porque não são mediadores ou especulativos entre êsses dois têrmos da produção e do consumo. Para que o ato econômico se transforme em ato jurídico. ou fato jurídico do comércio, é necessário que êle entre nessa circulação, nessa série de movimentos que há entre a prdoução e o consumo, isto é que seja um fenômeno econômico da circulação. Mas nem tôda a mediação, nem todo o ato entre a produção e o consumo pode ser considerado como um ato de comércio, ou, por outra, nem todas as mediações podem ser consideradas como ato de comércio, co- 
mo um dos seus elementos componentes. Já na produção, já no consumo, e principalmente na produção, há mediações que são consideradas atos de comércio. E muito bem observa Manara que o produtor é, não só produtor das utilidades que êle cria, que êle aumenta, mas é também consumidor de outras utilidades; o agricultor pratica um ato de mediação quando se dirige às indústrias fabrís para adquîrir os instrumentos necessários à sua lavoura. É também mediador quando entrega os produtos da lavoura à satisfação das necessidades do consumidor; entretanto, nenhum dos atos de comércio, não têm a mediação peculiar, essencial, singular de tais atos. A mesma cousa se dá em relação às indústrias fabrís: o industrial vai procurar a matéria prima - é, portanto, um intermediário entre a sua própria indústria e a indústria à qual êle vai buscar as máquinas, os utensílios, a matéria prima de que precisa para transformar em artefatos para depois vender ao consumidor. $\mathrm{Na}$ indústria extrativa, os indivíduos que exploram essa indústria também procuram os utensúlios necessários para a exploração das minas, por exemplo, e então são mediadores entre os produtores dêsses utensílios e máquinas de que precisam para aplicar na exploração dessas minas, e são mediadores em relação ao consumidor a quem entregam êsses minérios inteiramente transformados.

A mediação, para entrar como elemento do ato de comércio, precisa ser um ato principal. Desde que fôr secundária e auxiliar, não pode entrar como elemento componente do ato de comércio. A mediação, recaindo sôbre o fato principal, estabelece uma relação, um vínculo entre a produção e o consumo. Na sua definição, a ilustrada cadeira declarou que o comércio é essa mediação econômica com o fito de especular, preordenada à circulação das riquezas, e esta relação entre a oferta e a procura é que constitui o primeiro e principal elemento componente do ato de comércio.

A mediação, observa BESLAY, pode-se dar entre industriais diferentes, como entre a agricultura e o comércio. 
O comerciante vai ao agricultor, ao vinhateiro, compra o seu vinho e vai revendê-lo ao consumidor, na proporção das necessidades dêste. A mediação também se pode dar entre indústrias diferentes, tomada a palavra indústria no seu sentido próprio, restrito. O fabricante de panos vai procurar a matéria prima para transformá-la em artefatos para revender a outras indústrias que preparam os mesmos panos, como o alfaiate.

A mediação é, pois, elemento primordial, indispensável para a existência do ato de comércio.

- Vejamos a - especulação.

Além do sentido técnico, a palavra é tomada no de negociar, comerciar, em que é considerada como o segundo elemento para a construção da definição de ato de comércio. Os contratos de comércio são sempre onerosos, e contratos onerosos são aquêles que não são benéficos, são contratos que dão lucro, e êste lucro pode ser estimado em dinheiro. Um ato de comércio pode ser um ato de mediação, de intervenção na circulação; mas, si o movimento das riquezas não é guiado pelo pensamento de lucro, êsse ato não pode ser considerado como um·ato de comércio. É preciso haver na mediação o fito de ganhar. Sòmente nessas condições é que a mediação perde a sua amplitude geral para tomar o seu sentido restrito e servir de elemento predisponente à construção da nação de comércio.

Todos os atos humanos, mesmo os civis, são levados por um interêsse. Ninguém pratica um ato qualquer sem ser levado a essa prática por um interêsse mais ou menos intenso, mais ou menos enérgico; mas não é a especulação em geral que constitui um dos elementos do ato de comércio; é preciso que a mediação seja causa de lucro, que o comerciante especule sôbre a mediação. Desde que ela não esteja na relação do efeito para a causa, não pode ser considerada como elemento componente do ato de comércio. 
é preciso, além disso, que esta especulação, que recai essencialmente sôbre a mediação indispensável para que êsse ato seja considerado como elemento do comércio, é necessário que seja simultâneo ao ato da mediação. Supo nhamos o seguinte fato: há um indivíduo que quer entrar para a profissão comercial. Abre o seu estabelecimento, faz compras de tôdas as mercadorias que pretende revender ao consumidor ou a retalho, e, entretanto, antes de. operar a primeira vendu, como muitas vêzes acontece, êle. fecha o seu estabelecimento: todos os atos praticados por êste indivíduo, que comprou mercadorias com o intuito de revendê-las, isto é, de especular sôbre a mediação, são atos. comerciais. Êle responde pelas obrigações contraidas por êsses atos perante a jurisdição comercial, embora não tivesse realizado o seu lucro e a sua especulação porque não vendeu nenhuma das mercadorias.

Outro. Um negociante compra mercadorias para o seu próprio consumo, e, mais tarde, resolve vendê-las por lhe. sobrarem talvez das suas necessidades. Ėsse ato não é comercial porque a intenção do lucro não é simultânea à mediação, ao ato pelo qual êle comprou essas mercadorias. Ao inverso, si o negociante adquirir mercadorias para revender, e depois resolve dêstiná-las ao seu próprio consumo, o ato, nem porisso, deixa de ser comercial: a intenção. do lucro foi simultânea ao atơ da mediação. Não é o fato de lucrar que constitui a especulação comercial, mas apen nas a intenção do lucro, que, muitas vêzes, é obscura. O ato praticado pelo comercíante, um ato comercial por êle feito não denuncia, na sua exterioridade, a intenção que moveu o negociante a praticar êsse ato. Quem vê o comerciante comprar uma mercađoria qualquer, não sảbe se êle a comprou para o seu uso próprio ou para revendê-la. A intenção é elemento subjetivo e, porisso, surgem muitas vêzes obscuridades e incertezas quanto ao saber si o ato praticado pelo comerciante foi efetuado com o intuito de especular ou como um ato comum da vida. 
Além disso, especulação não quer dizer que o comerciante na realidade obtenha lucro nas operações em que entrou. Pode comprar mercadorias e revendê-las por preço abaixo do custo e, nem porisso, deixa de praticar um ato de comércio, porque deve haver o evento de dano ou de lucro, um elemento aleatório, como elemento predisponente do que se chama - especulação comercial.

Conclui-se, pois, que nem tôda a mediação mesmo entre a oferta e a procura, é um ato de comércio; é preciso que esta mediação seja o ato principal na operação do agente que pratica êsse ato, e que êsse ato seja preordenado à circulação econômica das riquezas. Nem tôda a especulação é um ato de comércio : é preciso que essa especulação seja simultânea ao ato da mediação e recáia sôbro ela; é preciso que esta especulação seja apenas um elemenio eventual, um elemento aleatório.

Êstes são os dois elementos que a escola clássica apresenta como característicos indispensáveis e uniformes do ato objetivo do comércio. Quando estudarmos o ponto seguinte, entrando na análise da natureza dos diferentes atos objetivos e subjetivos, veremos alguns atos considerados como atos objetivos de comércio pela escola clássica e nos quais falham um ou dois dêsses elementos.

Da exposição, não se infira que o ilustrado catedrático aceita as doutrinas da escola clássica: regeita in limine a possibilidade de se dar uma noção aproximada do que seja ato de comércio. Entre nós, mesmo na jurisprudência, na doutrina, vêem-se princípios estabelecidos em contrário da doutrina clássica. Encontram-se, principalmente na jurisprudência, atos do poder judiciário dispensando inteiramente a mediação como elemento indispensável para a criação do ato de comércio, e apenas dizendo que é necessário, tão sòmente, a especulação. Desde que um ato seja de especulação, levando em sị a intenção do lucro, para alguns tribunais isto só basta para desclassificar êstes atos da massa dos atos civís para serem considerados atos 
de comércio. Por aí se vê a incerteza que reina nesta matéria.

\section{IV}

Principais classificaçóes dos atos de comércio a) Atos objetivos ou absolutos; atos subjetivos on de relação: teoria do acessório.

b) Comercialidade dos atos por natureza, conexão ou depência, fôrça ou autoridade da lei.

c) Atos mistos.

Sistemas seguidos'nas legislações contemporâneas. Decreto n. 737 , de 25 de novembro de 1850 , art. 19.

A noção de ato de comércio dada pela escola clássica, como sendo uma mediação especulativa entre a oferta $e$ a procura, não abrange todos os atos que são disciplinados pelo Direito Comercial. Segundo a doutrina do chefe da escola clássica, VIDARI, a comercialidade de um ato depende do estudo, de investigação de sua natureza íntima; não é consentâneo com os princípios da ciência que o legislador deixe de parte o critério que lhe fornece a natureza íntima do ato objetivo de comércio, para criar um critério diferente que não está de acôrdo com a substância dêsse mesmo ato.

Ora, se a noção do ato de comércio não abrange todos os atos comerciais e considerados como tais na doutrina e na legislação, foi necessário, para se poder abranger tôda a série de atos comerciais, que se fizesse a classificação dêsses atos, e, então, se atribuisse a noção de ato de comércio dada pela escola clássica, tão sòmente aos atos objetivos de comércio, procurando-se uma fórmula científica para poder abranger os atos que não estivessem de conformidade com os elementos do ato objetivo de comércio. Daí, a necessidade das classificações. Os escritores da escola clássica, como adiante veremos, não estão de acôrdo 
sôbre o número e qualidade das classificações pelas quais se devem dividir os atos comerciais.

Atos objetivos de comércio são, segundo a escola clássica, aquêles que, por sua própria natureza, indicam os elementos da comercialidade.

A princípio a doutrina e as legislações apoiaram-se exclusivamente no elemento subjetivo do comércio. Todos os atos praticados por um individuo pertencente à corporação dos comerciantes eram, por êsse mesmo fato, considerados como atos comerciais. $\mathrm{E}$ atos, que, por sua natureza, deviam ser considerados comerciais, quando praticados por indivíduos que não pertencessem à corporação dos comerciantes, não eram, nem pela legislação, nem pela doutrina, considerados atos de comércio. Preponderava, então, o elemento subjetivo: era a qualidade da pessoa que praticava $o$ ato que refletia sôbre êsse mesmo ato, reunindo-o à conta dos atos comerciais. Mais tarde, porém, desaparecidas as corporações de artes e ofícios, implantado o sistema de liberdade do trabalho e do comércio, não sendo mais o comércio, como indústria, privilégio de uma classe, procurou-se saber por que modo se deveriam dirigir os legisladores e a doutrina para determinar quais os atos de Direito Privado que deviam pertencer ao Direito Comercial. Veio, pois, o sistema objetivo, deixando-se de lado o subjetivo, que não mais se podia invocar, porque haviam desaparecido as corporações de arte e ofícios, procurando-se, da natureza íntima dos atos, deduzir a sua comercialidade. Êste é o sistema em geral preponderante na doutrina e na legislação dos povos cultos. Sendo objetivo o ato comercial, é indiferente a qualidade da pessoa que o pratica. Qualquer indivíduo, que, por hábito ou não, sendo comerciante ou não, pratica um ato da ordem daqueles que a doutrina chama atos objetivos, êsse ato continua sendo comercial, muito embora tenha sido praticado, habitualmente ou não, por um comerciante ou pessoa que não exerça o comércio. Na doutrina alemã encontram- 
-se classificados como atos absolutos, atos que independem, por absoluto, das circunstâncias que os cercam, e têm, por conseguinte, na sua natureza, os dois elementos indispensáveis da comercialidade. Assim é que Endemann, estudando o antigo Código Alemão, dá a seguinte definição de ato de comércio: - é todo aquêle ato que, praticado habitualmente ou não, por comerciante ou pessôa que não seja comerciante, deve ser considerado como comercial.

Essta doutrina, porém, está perdendo terreno na ciência alemã, porque o novo Código, deixando de parte o critério objetivo, reproduziu o antigo critério subjetivo. Si no código alemão anterior os atos comerciais o eram por sua própria natureza, quando apresentavam os elementos da mediação e especulação entre a oferta e a procura, pelo novo Código de 1900 os atos comerciais são conside.rados exclusivamente na sua relação subjetiva, porque $o$ define como todo aquêle ato praticado pelo comerciante no exercício do seu comércio.

Os atos objetivos são, por sua natureza, comerciais, diz a escola clássica, são atos re ipsa mercantís, atos comerciais pròpriamente ditos. No seu Tratado sôbre os atos de comércio de relação, expõe Duchange perfeitamente êstes diferentes agrupamentos de atos de comércio. Entende que não é possível estabelecer um substractum idêntico para todos os atos de comércio, e diz que apenas pelo laço da forma é que se extremam os atos cívis de atos comerciais. Ele diz: na grande, na vária aglomeração dos atos da vida comercial podem ser encontrados dois grupos distintos: atos que, por seu próprio movimento, entram no domínio do Direito Comercial, e êstes atos são chamados - principais, absolutos ou objetivos pela escola clássica - e atos que entram sob o domínio da disciplina, das regras do Direito Comercial, não por um impulso próprio, mas por impulso estranho, e devem ser chamados atos de relação, 
subjetivos ou acessórios. $\mathrm{O}$ ato que entra por seu próprio movimento no domínio da disciplina do Direito Comercial, é um ato de comércio, não obstante as várias circunstâncias em que êsse ato se realize, ao passo que os atos relativos não podem ser comerciais senão quando se tornam uma dependência, uma acessão, quando se destinam própriamente a completar o ato principal do comércio.

É conhecida a definição dada por VIDari do comércio, e, por conseguinte, do ato de comércio. Elle declara que o ato de comércio é $o$ ato de mediação com o fito de especular entre a oferta e a procura. E pròpriamente o ato que promove, efetua, facilita a circulação das riquezas. Por essa definição aplicada à exposição de Duchange, vê-se que êle chama ato objetivo àquele ato que efetua, realiza a circulação das riquezas, e, ato relativo, subjetivo ou acessório àquele ato que sòmente promove, facilita ou auxilia a prática do ato objetivo, dos atos pròpriamente comerciais.

Esta noção não apresenta um critério seguro, é inteiramente falaz e não se aplica a todos os atos de comércio, mesmo aos atos de comércio objetivos.

Entre os atos de comércio alguns existem que dão em relêvo os elementos da mediação e da especulação. Tomemos como um ato típico, como ato modêlo das operações comerciais, a compra e venda. A compra e venda é um ato que revela mediação, é uma relação que se estabelece entre o produtor que cria as utilidades e o consumidor que precisa de adaptá-las às suas próprias necessidades. O contrato da compra e venda, pois, é um contrato de intervenção entre a produção e o consumo. E oferece também o elemento especulativo: o negociante que compra ao produtor os produtos necessários para o consumo, explora sôbre a passagem, explora sôbre a circulação dessas utilidades ou dêsses produtos, de modo que é um ato de especulação, o comerciante leva interêsse pecuniário nessa operação em que êle se intromete entre a produção e o con- 
sumo. Porisso é que, no Direito Romano, quando Ulpiane tentava definir o que era comércio, considerava como ato típico, das operações comerciais, a compra e venda, dizendo que o comércio era o direito recíproco de compra e venda. Assim também a doutrina e as legislações modernas a consideram e apresentam, em primeiro lugar, como exemplo do ato objetivo de comércio, a compra e venda. No nosso Decr. 737, de 25 de novembro, art. 19, na primeira classificação dos atos de mercancia, se indica exatamente a. compra e venda de efeitos móveis e semoverites.

Se realmente existem alguns atos que apresentam a mediação e a especulação perfeitamente definidas, frisantemente indicadas, outros atos, por absoluto, ou não apresentam o elemento da mediação ou o da especulação, e, apesar disso, a doutrina clássica considera-os como atos objetivos de comércio.

Vejamos um exemplo. Todos consideram como atos. objetivos de comércio as transações que giram em tôrno da letra de câmbio, que é hoje um papel de crédito que circula como a própria moeda e tem como interventores duas pessoas: o sacador ou credor e o sacado ou devedor. Podem ainda intervir nelas outras pessôas, como o endossante, todos êles sendo solidários e responsáveis pelo cumprimento e pagamento da letra. Ora, a letra de câmbia. nem sempre é um ato de especulação, nem sempre quem intervém nela tem o fito de lucrar ou de auferir vantagens. Com efeito, entre as letras de câmbio numeram-se também. as chamadas de favor, por complascência: um comerciante, que precisa de outra firma para poder descontar o seu título em um banco, dirige-se a um amigo, e êste, por comclacência, por favor (têrmos técnicos em Direito Comercial) presta a sua assinatura, sem outro interêsse que não. seja servir êsse amigo, ou como sacado, ou como sacador, ou como endossante da letra de câmbio. Mesmo em relaçãa aos atos objetivos, pois, não se pode dizer que seja geral 
a interferência da especulação para determinar a comercialidade dêsses mesmos atos.

Outro exemplo são os armazéns gerais, estabelecimentos que recebem mercadorias em depósito. Os armazéns gerais, que pertencem às corporações com fins civeis, não às comerciais, regulados peîa nossa lei de 21 de novembro de 1903, podem receber mercadorias em depósito, e, entretanto, não praticam um ato de comércio. Muito embora as mercadorias entrem nos armazéns gerais, êstes depósitos feitos nos armazéns das corporações cívis, considerados, aliás, como um ato de comércio, não têm, não oferecem 0 elemento da especulação, que, segundo a escola clássica, é o elemento indispensável para caraterizar o ato absoluto de comércio.

Com relação ao comércio marítimo, nós temos o contrato de fretamento, que é o aluguel que se faz de um navio para uma ou mais viagens. Quando estas são feitas para o transporte de mercadorias, que è uma operação acessória do ato de comércio, ainda se pode ver que êste fretamento piertence à soma, ao grupo dos atos de comércio objetivos. Mas quando se trata, por exemplo, do fretamento de um navio para uma expedição científica, bem se conclui que êste fretamento não pode ser considerado como tendo o elemento primordial da especulação, para ser tido na conta de ato comercial. Qualquer que seja o fim para o qual se frete, entretanto, o navio, ou seja para o transporte de mercadorias e passageiros, ou para fins inteiramente diferentes aos comerciais, como o transporte de uma expedição científica aos polos, êsses fretamentos são considerados, por sua própria natureza, atos comerciais, definidos e disciplinados pelo nosso Código nos arts. 566 e seguintes.

Há, também, atos de comércio em que falha o elemento da mediação. As legislações modernas consideram comu um ato comercial a compra de ações de companhias ou de sociedades comerciais, muito embora os indiviłduos que compram essas ações queiram apenas um emprêgo para 
o seu capital. Não é para especular, para revender, para tentar lucro, questão de ágio ou de cotação dêsses títulos que os individuos as compram, mas simplesmente para empregar as suas economias. Desaparece, pois, inteiramente, a mediação. Esses indivíduos que compram essas ações dessas companhias ou dessas sociedades não estabelecem uma intervenção comercial, uma mediação mercantil: êste é, entretanto, considerado pela doutrina e pelos códigos como um ato objetivo, absoluto e principal de comércio.

E preciso, portanto, concluir, mesmo com alguns escritores, como Manara, que estabelece a distinção entre atos subjetivos e objetivos, e entende que existem atos objetivos de comércio pela mediação e especulação, é preciso concluir com êles que, modernamente, a doutrina ainda não tem um critério uniforme para poder determinar a natureza íntima dos atos objetivos de comércio, e, por consequência, deduzir dessa natureza íntima os elementos de discriminação e classificação.

Há, além disso, na doutrina clássica, alguns pontos de contradição. Apontamos um. Vidari, que é o chefe incontestável da escola, e que, reproduzindo o que há pouco disse, declarou no seu Tratado de Direito Comercial que a comercialidade de um ato devia ser perscrutada na sua própria natureza, na sua essência, na sua substância, mais tarde virá dizer que não existem atos objetivos nem subjetivos de comércio, que é completamente incorreta a classificação daqueles que entendem que há atos comerciais por sua própria natureza, porquanto os atos comerciais apenas o são por um simples vinculo de relação. Em um artigo posteriormente publicado em seguida ao seu Tratado, declara que o verdadeiro caráter do ato está no fim com que é praticado pelo comerciante. Não é pela natureza intima dos atos, portanto, que se lhes pode descobrir a comercialidade, porisso que depende apenas do elemento intencional do indivíduo que pratica o ato. Se o fim do ato é comercial, êste ato é considerado como tal, e, se, ao contrá- 
rio, o fim não é comercial, o ato não o será também. Desaparece absolutamente o critério indispensável para indicar que os atos devem ser considerados comerciais por sua natureza, quando êle declara mais tarde que é apenas o elemento da intenção que carateriza êsse mesmo ato.

Ainda está em contradição com a sua definição de ato de comércio. Declara que atos de comércio são aquêles que efetuam a circulação das riquezas, ou que apenas a promovem e auxiliam. Por esta definição parecia admitir distinção entre atos objetivos, isto é: atos que, de fato, operam a circulação, e atos relativos, isto é: atos que apenas promovem a circulação das riquezas.

No entanto. vem mais tarde dizer que não se admite esta classificação dos atos em objetivos e subjetivos.

\section{Teoria do Acessório}

Chama-se ou diz-se teoria do acessório dos atos de comércio, aquela que estuda a natureza dos atos objetivos de comércio, em contraposição aos atos objetivos, atos comerciais pròpriamente ditos ou atos absolutos. É vária a denominação com que se caracterizam na doutrina êstes atos subjetivos: - uns os chamam atos de relação, outros — atos por destino, outros — atos relativos, outros - atos acessórios, outros — atos subjetivos, e outros - atos derivados. No direito alemão êstes atos são chamados: "negócios comerciais acessórios ou negócios comerciais derivados. Não é indiferente, entretanto, para a teoria do acessório dos atos de comércio, usar indistintamente de uma ou de outra dessas expressões. As expressões: atos subjetivos, atos derivados, atos acessórios, atos dependentes, atos conexos, com que a doutrina ordinàriamente indica êsses atos que entram na teoria do acessório, não exprimem perfeitamente a natureza dêsses atos. Seria melhor dizer: atos de relação, atos por destino, atos que: promovem, atos que facilitam a circulação das riquezas, isto 
é, atos que integram a comercialidade objetiva dos atos de comércio pròpriamente ditos.

No nosso direito não temos nem a expressão atos objetivos nem a expressão atos absolutos para determinar os atos de comércio pròpriamente ditos, e menos ainda temos denominação técnica com relação a êstes outros atos que entram na teoria do acessório dos atos de comércio. Assim, nos arts. 18 e 21, tit. único do nosso Código Comercial, só se fala em direitos e obrigações, atos ou obrigações que devem ser disciplinados pelo Direito Comercial.

Entre os escritores pátrios, o que melhor trata do assunto é o sr. Carvalho de Mendonça. Êle refere que os atos são chamados subjetivos quando têm uma relação intima, indissolúvel com os atos de comércio pròpriamente ditos; são atos que se referem ao exercício profissional do comércio e que integram o ato comercial na profissão mercantil. Chama também êsses atos: atos por conexão, atos por dependência.

Vejamos o fundamento da teoria do acessório.

A opinião geralmente corrente e perfeitamente elucidada por APPERT no seu Tratado dos atos comerciais terrestres, diz: o acesśório segue sempre o principal. Por isso, desde que o ato é um ato acessório, dependente, subserviente, como diz Duchange, êste ato deve ser considerado como um ato relativo, de destino comercial; não é um ato objetivo, mas simplesmente um ato subjetivo.

Esta teoria, entanto, encontra opositores, como DuCHANGE, por exemplo, quando trata dos atos de comércio por meio de relação. Entende êle que o princípio da teoria do acessório - $\mathrm{o}$ acessório segue o principal não é fundamento legítimo da teoria, porque, no direito francês, nem todos os atos acessórios podem ser considerados como comerciais. Assim, é doutrina corrente naquele direito que a fiança dada por um terceiro para garantir uma obrigação comercial, embora seja um atc dêste terceiro não é, no direito francês, considerado como 
um ato relativo de comércio, como um ato dependente de comércio. Segundo Duchange, portanto, não se pode dizer que êste princípio é absoluto: o acessório segue o principal, fundamento da teoria do acessório, porque há casos, como êsse apontado por êle, da fiança de um terceiro para garantia das obrigações comerciais, em que, apesar de ser o ato acessório, não é, entretanto, considerado como ato comercial.

Não aceitamos a teoria de Duchange porque a essa doutrina se opõem textos expressos do nosso Código Comercial. No art. 256, o legislador considera como ato comercial, como ato subjetivo de comércio, segundo a doutrina, a fiança prestada por um terceiro para garantia de uma obrigação mercantil do comerciante. Eis aí uma fiança, uma caução prestada por um indivílduo que não é comerciante, que não exerce profissionalmente a indústria do comércio, e que é considerada pelo Código como ato de comércio. Quando, pois, fôsse verdadeira essa teoria de Duchange, em nosso direito ela não pode ser aceita porque a ela se opõe o art. 256 do Código Comercial.

Para nós, pois, o princípio de que o acessório segue o principal, é que é o verdadeiro fundamento, a verdadeira base e a verdadeira explicação dessa teoria do acessório. porque êstes atos de natureza pròpriamente civil se referem ao comércio, dependem do comércio, facilitam o comércio, promovem o comércio e são uma consequência do comércio. $O$ ato comercial estende, por assim dizer, a sua comercialidade ao ato acessório, fazendo que o ato acessório figure como principal - e, como o ato principal pertence ao comércio, assim também o ato acessório deve pertencer.

Esta relação de dependência que existe, porém, entre os atos objetivos e subjetivos, ou a intromissão dos atos subjetivos no exercício da profissão comercial, não é uma relação pròpriamente subjetiva mas uma relação objetiva, é uma relação pròpriamente real. Neste ponto não estão 
acordes os escritores. Alguns entendem (e parece ser essa a doutrina aceita pelo nosso Código Comercial), alguns entendem que a relação que prende, que liga o ato acessório, o ato civil ao ato comercial, dá, empresta-lhe o seu caráter de objetividade. Outros são de parecer que esta relação é uma relação puramente subjetiva, é preciso que a pessoa que pratica o ato seja comerciante e que pratique êsse ato em benefício, no interêsse e em virtude da sua exploração comercial. Essa relação, portanto, dizem êles, é uma relação puramente subjetiva, não é uma relação objetiva. A opinião que ao douto catedrático parece melhor é a que declara que esta relação que existe entre êsies atos não é uma relação puramente subjetiva, mas é uma relação real, é uma relação objetiva. Dois exemplos bastarão pará indicar a plausibilidade desta doutrina.

Não se discute, qualquer que seja o direito que se invoque, que todos os atos praticados por um indivíduo que deseja exercer a profissão comercial, mas que, de fato, ainda não a exerceu, pertencem ao quadro dos atos de comércio. Todos os atos que se predestinam, que visam o lucro, têm um fim comercial. Suponhamos que o individuo, que se quer estabelecer, abra o seu estabelecimento comercial. É preciso que êle se proveja de todo o material n€: cessário para a exposição das suas mercadorias, o balcão, a mobília, a armação, etc.; é preciso tirar licença do poder público; é preciso fazer anúncios, expedir circulares; é preciso acondicionar essas mercadorias em uma casa, alugar ou adquirir uma casa suficiente para o negócio. Todos êsses atos são considerados uniformemente, por todos os direitōs positivos, como atos pertencentes ao comércio. Esse indivíduo, que assim compra êsses objetos e se provê do material indispensável para o exercício do comércio, não se pode dizer que seja comerciante, porque a qualidade de comerciante depende da habitualidade da profissão; é preciso que êle exerça efetivamente a profissão, para que 
possa ser cnosiderado comerciante. Estão aí, pois, praticados atos por um indivíduo que não é comerciante e que são comerciais pelo fim a que propendem.

Não é a relação subjetiva, pessoal, portanto, que im-prime a comercialidade ao ato acessório, mas é uma relação real, objetiva; é porque êste ato se refere aos atos de comércio, tem uma relação objetiva, uma relação real com o ato de comércio; êstes atos são acessórios do ato de comércio, e, por conseguinte, são considerados na mesma linha, no mesmo nivel que os atos objetivos de comércio.

Nem todos os atos praticados na dependência ou na relação dos atos objetivos de comércio, entretanto, podem ser considerados como comerciais. Os códigos modernos os distinguem perfeitamente sob todos os pontos de vista. Eles classificam os atos de comércio em: atos de comércio por sua própria natureza e atos de relação ou subjetivos. Dizem, não obstante, que não podem fazer corpo coin os atos de comércio relativos ou subjetivos aquêles atos que são essencialmente civís, e cuja natureza civil repele a comercialidade. E, assim, apresentam alguns exemplos: os atos civís que se resolvem no direito de família, não podem, de modo algum, fazer parte do comércio, não se podem constituir como atos de comércio, não podem fazer parte da especulação mercantil. Assim, também, no nosso direito, tôdas aquelas operações que recaem sôbre bens imóveis ou bens de raiz, não podem fazer parte do comércio, porque o nosso Direito Comercial não quer incluir os imóveis nas transações comerciais. Esstes atos, por conscguinte, muito embora sejam praticados por um comerciante em benefício, no interêsse ou em virtude do seu comércio, por disposição expressa do nosso Direito, não pıdem ser considerados comerciais em caso algum. Fora dêste limite, fora desta restrição, todos os atos de Direito Civil, principalmente todos os que se referem a questões patrimoniais, a relações patrimoniais, podem fazer parte do 
comércio, podem sôbre êles recair obrigações comerciais. Estes atos podem se transformar em atos comerciais.

Vejamos agora a aplicação, segundo o direito pátrio, desta teoria do acessório.

Como sabemos por estudos do Direito Romano, cinco são as fontes principais das obrigações. A obrigação é o vínculo que obriga as partes contratantes a dar, fazer ou omitir qualquer fato. A obrigação de fazer, de praticar certo fato, de omitir êsse fato, deriva-se das seguintes fontes: ou são fontes contratuais em que, por acôrdo das partes contratantes, apiarece o vínculo da obrigação; ou esta obrigação deriva do quasi-contrato, isto é, de um ato lícito a que a lei presta eficácia; ou a obrigação pode derivar de um delito, que é um ato ilícito doloso, que é um ato ilícito culposo; ou de um quase-delito. Vejamos, nesta ordem, quais são os atos relativos, quais são os atos da teoria do acessório em Direito Comercial, que se derivam: - da fonte contratual, do quase contrato, do quase delito e da obrigação d da lei.

E preciso - para que um ato comercial que não é da ordem daquele que a escola clássica chama atos objetivos, isto é, não é da ordem daqueles que sejam mediação e especulação - é preciso que os atos, para que se tornem acessórios, tenham uma dependência íntima, indissolúvel com os atos principais, com os atos comerciais pnòpriamente ditos. Todos aquểles contratos, pois, a que, por convenção feita por vontades livremente consentidas, se refere essa obrigação indissolùvelmente, intimamente, dependentemente dos atos de comércio, são considerados como de Direito Comercial.

Temos, portanto, uma fonte copiosa de atos relativos de comércio na convenção das partes, isto é, na obrigação contratual. No caso acima citado: o comerciante precisa de mobiliar o seu estabelecimento, precisa de armação, de balcão, pesos e medidas, de livros comerciais onde escritu- 
re tôdas as suas transações. Todos êstes atos, são de natureza pròpriamente civil, mas como êles se destinam ao interêsse, em virtude do exercício do comércio, êstes atos, que não eram, por sua própria natureza, senão atos de ordem civil, transformaram-se em atos de ordem comercial.

A mesma cousa se pode dizer com relação ao ajuste feito pelo comerciante com os empregados de que êle precisa para a exploração do comércio, caixeiros de balcão e viajantes, guarda-livros, etc. Êstes ajustes, embora sejam, por sua natureza, atos civeis, se transformam em atos comerciais, são atos dependentes, relativos, atos que se destinam ao exercício da profissẫo comercial. O mesmo princípio se aplica com relação à compra de combustível para as máquinas. A compra de combustivel é um ato puramente civil, e, no entanto, quando os combustíveis são aplicados à propulsão das máquinas industriais. êsse ato perde o caráter de ato civil para tomar o caráter comercial, para receber o cunho da comercialidade. Com relação à venda ou trespasso dum estabelecimento comercial dá-se ainda o mesmo. $O$ indivíduo que vende a outro o seu estabelecimento comercial, incorpora à venda o ativo e passivo. Este ato se considera como um ato comercial, isto é : à exploração do comércio, êste ato perde o seu caráter de ordem civil para assumir o caráter com relação à fiança. A fiança é um contrato acessório que garante uma ação principal. Quando êste contrato, que é de ordem civil, vai garantir uma obrigação comercial, quer o fiador seja comerciante, quer não, êste contrato passa a ser de ordem comercial, tornando-se comercial. É um ato da natureza daqueles que os jurisconsultos chamam - atos neutros, por que se podem aplicar, não só com fim pròpriamente comercial. A mesma cousa dá-se com o penhor, que pode ser dado por um outro comerciante, por um terceiro. $O$ penhor dado para garantir, para assegurar uma obrigação, é um ato, em si, puramente civil; mas, quando vai assegurar uma 
obrigação comercial, é um ato que se torna de natureza comercial. Dá-se o mesmo com as cartas de crédito, que, sendo de ordem civil, podem servir, tanto para as relações de Direito Civil como para as de Direito Comercial, porquanto, quando aplicadas ao Direito Comercial, perdem o caráter primitivo para assumir o de um ato de comércio.

Tôdas estas aplicações se encontram nos arts. 256, 271, e 274 do nosso Código Comercial.

Eis aí uma fonte copiosa de atos do gênero dos atos relativos de comércio, derivados da primeira fonte, isto é, da contratual.

Mas existem atos lícitos que, embora para a sua formaçâo não intervenha segunda vontade, como nos contratos, entretanto a lei, com relação a êles, reconhece a sua eficácia. Êsses atos lícitos dos quais deriva uma obrigaçãó sem que se verifique um ajuste são os quase-contratos.

A conditio indebiti é uma forma muito saliente dó quase contrato. $\mathbf{E}$ um indivíduo que, supondo dever a outro, paga. Se a obrigação para êle existe, é só por supor que entre si e o credor há um vínculo de obrigação. $O$ indivíduo, que assim paga, poder rehaver aquilo que pagou em cumprimento de uma obrigação que não devia. Eiś aí caso de um quase contrato gerando um ato relativo dá teoria do acessório.

Outro caso bem conhecido è o da gestão de negócios. $\mathrm{O}$ indivíduo que, por afeição a um comerciante, gere sem mandato seu um ato pertencente ao comércio, pertencente à profissão comercial dêsse comerciante, estabelece uma gestão de negócios, e a lei dá eficácia, dá valor a êstes quase contratos, porque obriga o comerciante, em benefício de quem o terceiro gere seus negócios, a indenizar tôdas as despesas feitas pelo gestor do negócio em benefício do seu administrado, segundo o art. 103 do Código Comercial. Aí se diz que um comerciante pode gerir sem mandato os negócios de outro comerciante, mas que êsse comerci- 
ante em benefício de quem êle administra êsses negócios é obrigado a indenizar o seu gestor das despesas feitas com a gestão.

A mesma cousa se dá com relação às avarias grossas, de Direito Mercantil, e que são todos os prejuizos, todos os danos que sofre a carga de um navio ou o próprio navio. Se êsse prejuizo, se êsse dano recai sôbre um só objeto da carga do navio, essa avaria é chamada avaria simples; são, porém, avarias grossas, quando redundam em prejuizo total. Êste dano na carga, em benefício, por exemplo, da salvação comum, no caso de perigo de um naufrágio, em que o navio esteja demasiadamente sobrecarregado, é chamado avaria grossa. O capitão do navio pode alijar a carga que pesa no navio para o aliviar, a ver si assim o salva do naufrágio. Os danos assim acontecidos são chamados avarias grossas, porque tôdas as outras mercadorias, embora não sofram, são obrigadas a entrar com o seu quantum para indenizar os prejuizos. Eis um caso perfeitamente caraterístico de um quase contrato: as mercadorias salvas são obrigadas a entrar com com a sua quota parte, proporcionalmente, para cobrir os prejuizos derivados, por exemplo, no caso proposto, do alijamento da carga ao mar.

Vejamos, agora, outra fonte de obrigação da teoria do acessório: o delito, que é todo ato ilícito em que intervém o dolo. Há delitos civis e comerciais. Dos delitos comerciais apontamos apenas dois, como exemplo da teoria do acessório dimanando do delito.

O comerciante, uma vez que registre a sua firma, a sua razão comercial, tem propriedade exclusiva sôbre essa firma, essa razão comercial. Desde que êle registre perante as juntas comerciais o seu nome comercial, a sua firma ou a sua razão comercial, nenhum outro indivíduo pode usar dela no exercício de qualquer ato de comércio. Desde que, porém, há um terceiro que abuse da firma ou 
razão comercial que não lhe pertence, a lei considera êsse fato como ilícito, como doloso, e não só pune criminalmente o indivíduo que pratica êsse abuso, impondo-lhe uma pena, como ainda o obriga a ressarcir todos os prejuizos. que com essa usurpação êle causou ao dono da firma. Eisaí ưm delito comercial e uma obrigação de indenizar que é um ato relativo da teoria do acessório.

A mesma cousa se dá com relação à usurpação, ao abuso das marcas de fábrica ou de comércio. O comerciante tem o direito de indicar por um modo sensivel todos os seus produtos, todos os produtos que êle expõe à venda, com certos sinais distintivos que permitem diferençar êsses produtos de outros produtos similares. Se um indivíduo a quem não pertence a marca, porque ela é propriedade exclusiva de quem a regista, se utiliza dela, comete um delito comercial, prejudica ao comerciante cujo gênero está acreditado, que tem largo consumo. $\mathrm{E}$ quem assim abusa, usurpa essa marca de comércio, essa marca de fábrica, tem obrigação de indenizar o proprietário legítimo de todos os prejuizos a êle causados. Eis ai ainda uma obrigação comercial de atos relativos de comércio procedentes da fonte do delito. Apesar dos exemplos indicados, entretanto, e exempos que estão aceitos nas legislações, como em relação ao caso do abuso de marca de fábrica ou de comércio (lei de 14 de outubro de 1882, regulamentada pelo dec. de 30 de dezembro dêsse mesmo ano) ou do abuso da razão comercial (decr. de 16 de outubro de 1890) ; apesar de estarem perfeitamente esclarecidos por disposição expressa do nosso direito, êstes casos em que a obrigação comercial deriva, já do delito, já do quase delito; há, entretanto, jurisconsultos pátrios que negam a sua comercialidade.

Quando se fala comercialmente do delito ou do quase delito, não se quer dizer que o delito ou que o quase delito. possam ser objeto de exploração comercial. 0 comerciante usurpa a razão comercial de outro em benefício do consumo ou em beneficio do seu próprio produto sôbre o 
qual êsse explora; um individuo na indústria de transporte produz um dano a qualquer pessoa, esmaga ou atropela um indivíduo: eis um quase delito cometido no exercício do comércio. Mas esta teoria do delito e do quase delito. como fonte de obrigações, e, pois, como fonte de atos relativos de comércio não é uniformente aceita, já na doutrina estrangeira, já no Direito pátrio. Entre outros, o sr. INGLÊS DE Souza entende que o delito e o quase delito. não podem ser considerados como fonte de atos relativos. de comércio, que o delito e o quase delito não se podem transformar em atos comerciais por dois motivos: $10^{\circ}-\mathbf{o}$ argumento doutrinal, $20^{\circ}$ por disposição expressa da nossa lei, que repugna completamente à comercialidade dos atos. de comércio derivados do delito e do quase delito. $\mathrm{O}$ argumento doutrinal consiste em dizer que o crime ou delita, ou quase delito, constituem matéria de D. Penal; e, como o D. Penal pertence ao D. Público, e o D. Comercial pertence ao D. Privado, não se pode transformar uma relação. de D. Público em uma relação de D. Privado, tornando comerciais os atos derivados do delito e do quase delito. o segundo argumento em que êle procura firmar, é a lei: refere-se à disposição do art. 68 da lei n. 26 , de 3 de dezembro de 1841, que trata da ação de indenização do dano causado por delito, dizendo dever ser apresentada por ação civil. Quando se promulgou o Código de Pro-. cesso Criminal de 1832, o legislador entendeu que a mesma sentença devia determinar o valor da indenização do dano causado. Cometido o crime, incorre o delinquente em dois. efeitos jurídicos: - a repressão do crime e a reparação do dano causado pela indenização dêsse mesmo dano. No domínio do Código de Processo Criminal, a mesma sen-. tença, não só impunha a pena, como também determinava o quantưm da indenização do dano causado. Sobrevindo. a lei de 3 de dezembro de 1841, art. 68, determinou duas consequências derivadas da perpetração do crime: no que dizia respeito à imposição da pena, deixou afeta à juris-. dição criminal; no que dizia respeito à indenização do dano, 
desaforou, segundo o têrmo aí empregado, da jurisdição criminal para atribuir 'à jưrisdição civil, e mandou que, si pela ação criminal se podia impor a pena, sòmente pela ação civil se poderia pedir a indenização do dano. Isto foi reproduzido no art. 76 do Código Penal, onde se diz que a indenização do dano deve ser sempre pedida por ação civil. Ora, dessas duas disposições, provém a teoria que regeita a comercialidade dos atos relativos da teoria do acessório. A teoria entende que êsses artigos se opõem à comercialidade dêsses atos por não falarem em ação comercial, dizem.

O primeiro argumento, o doutrinal, é de dizer-se que o delito é uma relação de D. Público, porquanto o D. Penal, que deve determinar, proibir o delito e impôr a pena, pertence ao D. Público. A confusão daqueles que entendem que êste argumento é procedente, provém de que êles não consideram no delito dois aspectos diferentes - o aspecto puramente público e o aspecto estritamente privado. Além da consequência penal, o delito importa uma consequência civil, na reparação do dano. O delito pertence a duas relações diferentes: por um lado, em relação à pena, pertence ao D. Penal; por outro, com relação à indenização do dano causado, pertence à jurisdição civil. Além disso, quando a lei de 3 de dezembro de 1841, art. 68 , se refere à jurisdição civil, neste têrmo - civil - ela compreende não só o D. Comercial como ainda o D. Civil. A denominação - civil - é muitas vezes empregada em contraposto à denominação - criminal: legislação civil, legislação criminal; mas, quando se diz: legislação civil, se compreendem não só as relações ou normas de D. Civil pròpriamente dito, como as relações ou normas de D. Comercial. Dizer, portanto, que o $\mathrm{D}$. Comercial não pode conter em si a comercialidade dos atos relativos de comércio oriundos do delito, dizendo que o delito ou o quase delito pertencem a uma relação de D. Público, importa em confundir os dois aspectos em que pode ser considerada esta infração 
da lei penal que se chama crime ou delito. Ademais, não se podem considerar como sinônimos o crime no D. Penal e o delito no D. Civil ou Comercial O crime, no D. Penal, deve ser previsto pela lei: ninguém pode ser processado ou sofrer uma pena sem ser em virtude de um delito que tenham sido determinado pela lei penal. Ora, há infrações extracontratuais ou aquilianas que não estão previstas pelo Código Penal, não são passíveis de pena certa, e, entretanto, se consideram como delitos civis.

Que é, pois, delito, no ponto de vista de D. Privado? Delito é um ato ilícito, danoso, previsto ou não pela lei penal, com o fito de prejudicar alguém. A expressão previsto ou não pela lei penal, que entra como elemento da definição do delito civil, importa em esclarecer esta distinção que há entre o crime pròpriamente dito e o delito, entre o crime, como infração da lei penal, e o delito, como um fato da lei civil. Não se trata, aqui, do que se chama culpa contratual. Há uma distinção entre culpa contratual e a culpa extracontratual ou aquiliana: aquela resulta da ação ou omissão de uma obrigação que foi expressamente compreendida no contrato; e esta é a ação ou omissão que não resulta do contrato, mas importa em dano das partes contratantes. Se o delito é um ato ilícito, danoso, previsto ou não pela lei, em prejuizo de outro, o quase delito é também um ato danoso e ilícito, previsto ou não pela lei penal, em detrimento de outrém. A distinção está em que, para haver delito civil é necessário que haja dolo, que haja a intenção de cometer a ação ou omissão que importa em prejuizo de terceiro, e quanto ao quase delito, não é preciso essa intenção, ou, antes, essa intenção é excluida, como no caso de culpa, de negligência, em que o indivíduo não é dolosamente levado a cometer o delito, a ação ou omissão, mas, entretanto, por sua imprudência, negligência comete a infração. O delito é cometido com o fito de prejudicar; e o quase delito, sem a intenção de prejudicar. 
O outro argumento da teoria que não aceita a comercialidade dos atos relativos e acessórios derivados do delito e do quase delito, é o que se firma no art. 68 da lei de. 13 de outubro de 1848 . A lei de 14 de outubro de 1882 , que legislou sôbre as patentes de invenção, declara que aquêle que usurpa, usa ou emprega ilegalmente uma marca de fábrica, de comércio ou de indústria, incorre numa multa, na obrigação de ressarcir o dano, a indenizar os prejuizos causados pelo uso ilegal dessa marca de fábrica, de comércio ou de indústria. Uma vez, pois, que a lei obriga o infrator da marca de fábrica a reparar o dano causado, reconhece claramente que a comercialidade pode se dar com relação ao delito ou ao quase delito, quando esta marca de fábrica seja usada com intenção de prejudicar ou quando seja usada sem uma tal intenção. A mesma cousa se pode dizer com relação aos direitos autorais. A lei de $1 .^{\circ}$ de agôsto de 1898 , estabelecendo o organismo da propriedade literária ou artística, declarou que aquêle que não é dono da obra artística ou literária, não pode usá-la ou explorá-la quando viola os direitos autorais, e é obrigado a indenizar o autor dessa propriedade de todos os prejuizos, de todos os danos causados pelo abuso que fêz da propriedade alheia. É mais um argumento em favor da doutrina que vimos sustentando. A mesma cousa se pode dizer com relação às patentes de invenção ou de comércio. A lei de 14 de outubro de 1887, diz que aquêle que, ciente ou inconscientemente, usa de uma patente de. invenção que não é de sua propriedade, é obrigado a indenizar o dono dessa patente de invenção por todos os danos que lhe causou.

Na legislação pátria, como se vê, encontram-se disposições precisas reconhecendo a comercialidade dos atos relativos resultantes dos delitos e quase delitos.

Na sua monografia sôbre os atos de comércio, o sr. Carvalho de Mendonģa diz que, segundo o D. Comercial 
pátrio, os atos de comércio podem ser classificados em três classes: atos de comércio por natureza, atos de comércio por conexão ou dependência e atos de comércio por fôrça ou autcridade da lei. Ao expender esta sua opinião, êle confessa que nas legislações dos povos cultos o legislador não se deixou levar por considerações abstratas ou científicas, não se sujeitou a um critério lógico quando fêz a discriminação dos atos de comércio. Daí, a enorme diversidade que há com relação aos sistemas que os legisladores seguiram quando trataram de determinar nos códigos comerciais a enumeração dos atos de comércio. Ora, o nosso D. Comercial positivo proveio dos códigos da França, Portugal e Holanda, e é unânime a opinião dos comercialistas francêses em declarar que o legislador de 1807 , assim como os legisladores posteriores francêses, os portuguêses e os holandêses, não obedeceram a um critério científico, não aplicaram nenhum princípio de ciểncia à enumeração dos atos de comércio que vêm catalogados nos diferentes códigos. $\mathrm{O}$ nosso Código, procedente do francês, também não obedeceu a nenhum critério científico. Entendeu, pois, o sr. Carvalho de Mendonça aplicar um plano doutrinário a esta numeração confusa feita pelo nosso Código Comercial, e apareceu a sua classificação. Êle chama atos de comércio pròpriamente ditos não sòmente àqueles atos de comércio que são por sua própria natureza e índole comerciais, como ainda àqueles atos que, sendo civis por sua natureza, entretanto, por sua relação e dependència com os atos comerciais pròpriamente ditos, entram no regime do D. Comercial. Daí vem êste primeiro membro da sua definição: atos de comércio pròpriamente ditos por natureza e atos de comércio pròpriamente ditos por conexâo ou dependência. Além dêstes atos relativos, ainda há atos que entram para o domínio do D. Comercial por fôrça ou autoridade da lei; a lei arbitràriamente desaforou os atos civis para incluí-los na classe dos atos comerciais - são os atos comerciais por fôrça ou autoridade da lei. 
Se êle se tivesse limitado ao terreno da doutrina no estabelecimento da sua classificação, poderíamos recebêla, embora ela, mesmo sob o terreno doutrinal, apresente defeitos e lacunas, mas o alcance desta classificaçâo é sistematizar, igualar num corpo doutrinal a enumeração dos atos de comércio feita pelo nosso Código. Neste ponto, absolutamente não tem razão o dr. Carvalho de Mendonça porque a sua classificação em atos de comércio própriamente ditos e atos de comércio por fôrça ou autoridade da lei não se ageita, não se informa no nosso direito positivo. O nosso Código Comercial não usa da expressão atos de comércio. Fala-se, sim, em atos e obrigações comerciais, atos de mercancia, negócios comerciais. Para estabelecer, debaixo do ponto de vista da nossa legislação, assento à sua primeira classificação de atos de comércio por sua natureza ou atos de comércio própriamente ditos, o dr. Carvalho de Mendonça se refere aos arts. 17 e 21 do Código e 19 do decr. 737, de 25 de novembro de 1850 . No art. 18, título único do Código, o legislador diz que devem ser submetidas à legislação comercial todos os atos ou tôdas as causas derivadas dos direitos cu das obrigações regidas pelo Código. No art. 21 reproduz o mesmo pensamento, dizendo que todo o juiz ou tribunal que se tenha de pronunciar sôbre questões de atos ou negócios comerciais deve aplicar a legislação do Código, e no art. 19 do decr. 737 de 25 de novembro de 1850 o legislador enumera como atos de mercancia os diferentes atos cuja compreensão, cujo efeito jurídico êle determina. No corpo do Código êle determina as normas para reger essa mesma compreensão, êsses mesmos efeitos, essas mesmas consequências. Dissemos que, em relação ou em confronto com o nosso direito positivo, era improcedente a classificação. Èle diz que todos os atos de comércio por sua própria natureza ou atos de comércio por conexão ou dependência estão incluídos nestes três artigos 18 e 21 do Código e 19 do Decr. 737 de 25 de novembro de 1850 . Ora, basta con- 
frontar esta sua teoria e essas disposições do código para se ver que essa classificação nâo calha, não se informa com o preceito legislativo do nosso Código Comercial. Êle chama atos de comércio por sua própria natureza aquêles que nós chamamos atos objetivos, atos absolutos, isto é, aquêles que na doutrina clássica contêm em si os elementos da mediação e da especulação, e êstes atos estão previstos no art. 19 do decr. 737 de 25 de novembro de 1850 .

Atos por conexão ou por dependência: Ele chama assim os atos relativos de comércio. Ora, os atos relativos de comércio não são sòmente aquêles que têm uma relação subjetiva, mas são exclusivamente aquêles que têm uma relação objetiva. A relação que prende os atos por conexão ou por dependência aos atos comerciais pròpriamente ditos, ao exercício profissional do comèrcio, é uma relação objetiva e nem sempre uma relação subjetiva; e então o exemplo é o do caso assás conhecido do indivíduo que quer abrir um estabelecimento comercial, e que, antes de ser comerciante, pratica atos preparatórios para êsse comércio. É assim que a legislação os considera como atos relativos de comércio, independentemente da relação subjetiva, porque, então, o agente dêsses atos, na ocasião em que os praticava, não era ainda comerciante. Temos também o caso do individuo que interrompe o exercício do comércio e deixa de ser comerciante, porque, pelo nosso Código, não há comerciante sem a efetividade do exercício, segundo o art. 4. Este indivíduo praticava atos do interêsse do seu comércio, visando fins comerciais: praticar atos de comércio, embora relativos aos atos objetivos, não é um vínculo subjetivo, mas objetivo. Ora, quando o dr. Carvalho de Mendonça trata de descrever os atos por conexão ou por dependência, e, pois, os atos por sua natureza comerciais, êle exclui os atos que pertencem ao D. Comercial, como no caso do art. 256. quando se trata da fiança, em que o legislador determina que a fiança, para ser comercial, é necessário que intervenha para garantir, para 
assegurar uma obrigação comercial, muito embora o fiador não seja comerciante. Êste ato da fiança, o dr. Carvalho de Mendonça o inclui entre os atos que são sujeitos à jurisdição comercial, não só em relação à pessoa como em relação ao ato, quando aí não se trata absolutamente de uma relação subjetiva, mas sim de uma relação objetiva.

Esta classificação não se ageita com o nosso direito positivo. A única classificação que poderá servir é justamente aquela de que tratam os dois primeiros capítulos do decr. 737 de 25 de novembro de 1850. Aí se trata de jurisdição comercial com relação aos atos e com relaçâo às pessoas e da jurisdição comercial sòmente com relação aos atos, o que importa em o legislador declarar que existem atos que, independentemente da consideração pessoal do agente que os pratica, são comerciais, e o são, não só por sua própria natureza, mas ainda que, para serem considerados como comerciais precisam de ser praticados por comerciante. No primeiro dêsses tifulos, art. 20, se diz: serão julgados de conformidade com as disposições do C.ódigo, pela mesma forma e processo, ainda que não intervenha e comerciante. tais e tais atos comerciais. Aqui o legislador toma o ato de comércio apenas na sua relação objetiva, pondo de parte tốda a consideração pessoal para que as sociedades comerciais não possam ser prejudicadas por êste ou aquêle individuo. Com relação ao cap. $3 .^{\circ}$, do decr. 737, de 25 de novembro de 1850, diz-se: a jurisdição comercial segue a pessoa do ato, ou, competem $\dot{a}$ jurisdição comercial tôdas as causas que derivarem dos direitos $e$ obrigações comerciais, contanto que uma das partes seja comerciante. Êstes atos, que o legislador relaciona nos arts. 10 e 11, embora sejam atos por sua própria natureza comerciais, umá vez que nêsses atos não intervenha ao menos uma pessoa que seja comerciante, o Direito não os considera como atos comerciais, nem como sujeitos à jurisdição comercial. Se o dr. Carvalho de Mendonça se tivesse limitado a dizer: o nosso Código Comercial considera os atos comerciais debaixo de duas relaçóes, na re- 
lação objetiva quando fala da legislação comercial, atos comerciais independentemente da pessoa que os pratica, e considera ao mesmo tempo a relação subjetiva e objetiva, quando ela rege, disciplina os atos que são praticados pelo comerciante, uma classificação desta ordem, concebida nestes têrmos poderia ser considerada como uma classificação legal; não, porem, como ele a concebeu, em atos pròpriamente ditos comerciais, isto é, atos por natureza, atos por dependência ou por conexão comerciais, e atos que derivam própriamente da lei, da fôrça ou da autoridade da lei.

Quando trata de discriminar os diferentes atos comerciais que são considerados mercantís por fôrça ou autoridade da lei, êle inclui nos atos que diz que são comerciais por fôrça ou autoridade de lei, atos que pertencem aos atos relativos por conexão ou por dependência. Assim, com um simples exemplo, êle diz que os atos ou obrigações referentes ao seguro, ao fretamento de D. Marítimo, são considerados atos comerciais, quando o não sejam, diz êle, por conexão ou dependência dos atos ou do exercício profissional do comércio, porque a lei assim o ordena. Basta considerar o que seja um seguro ou um fretamento para se verificar que êstes atos não são comerciais por fôrça ou autoridade da lei, mas sim porque se referem, estão na dependência, na conexão com o exercício do comércio. 0 seguro que é feito, por exemplo, para garantir contra o fogo uma casa, não se considera como comercial porque o seu fim não é comercial, trata-se apenas de resguardar um direito privado - o de propriedade. Mas quando o comerciante põe no seguro o seu estabelecimento comercial, êle trata de garantir, de pôr em segurança êsse seu estabelecimento, portanto o fim è comercial. Está, aí, pois, um seguro que, conforme o fim a que êle se destina, pode ser comercial, inteiramente comercial, ou civil, inteiramente civil. Esses atos, entretanto, que segundo o fim a que êles se destinam, estão na dependência dos atos comerciais, de- 
vem ser considerados como atos relativos de comércio, o dr. Carivalho de Mendoça os inclui no número dos atos comerciais por fôrça ou autoridade da lei.

Além destas duas classificações geralmente aceitas, em atos objetivos e subjetivos de comércio, há outras que mais. ou menos reentram nessa classificação, como as de Obarrio, Appert e Thaller.

Obarrio, sem critério algum científico, distribui os atos comerciais nas seguintes classes: atos comerciais re ispaaquêles que, por sua forma, entram no quadro dos atos. comerciais, e êle apresenta como exemplo a letra ou as. operações de câmbio; atos comerciais ratione personae aquêles que são considerados tais em virtude da consideração do agente ou da pessoa que pratica êsses atos; atos acessórios ou auxiliares - aquêles que, não promovendo, não efetuando os atos comerciais, entretanto auxiliam a sua realização, como as operações de corretagem; atos comerciais por sua forma - aquêles que se revestem de forma comercial, como a letra de câmbio, as sociedades anônimas.

A classificação de APPERT é tripartida: distribui os atos comerciais em atos de comercialidade objetiva, atos que, por sua natureza, pela mediação e pela especulação devem ser considerados mercantỉs; atos de comercialidade subjetiva, em que sòmente a pessoa do agente é que apresenta o cunho da comercialidade pelo ato que ela pratica; atos de comercialidade pela forma - aquêle atos da vida civil que, uma vez revestidos da forma própria, da forma peculiar ao D. Comercial, devem ser considerados como atos mercantís, e apresenta o exemplo clássico da letra de câmbio, as sociedades anônimas e as sociedades civis que revestem a forma das sociedades comerciais.

Distribui Thaller os atos de comércio em três classes: atos de comércio principais, compreendendo os atos objetivos ou atos por sua própria natureza comerciais; atos acessórios, e com isto êle quer compreender os atos sub- 
jetivos; e atos por sua própria natureza não comerciais ou atos mistos, isto é, atos bilaterais.

Vejamos os atos comerciais mistos, isto é, os atos comerciais bilaterais e atos comerciais unilaterais.

Chamam-se atos bilaterais de comércio aquêles em que interveem duas partes comerciantes, isto é, em que as partes contratantes são uma e outra comerciantes; são, pois, atos comerciais tanto para uma como para outra das partes contratantes; atos unilaterais são, ao contrário, aquêles que sòmente são comerciais para uma das partes contratantes, conservando a sua natureza de ato civil para a outra das partes contratantes. Assim, quando o negociante pror grosso vai aos centros de produção adquirir as mercadorias ou produtos do produtor, êste ato é um ato unilateral, é um ato comercial para o comerciante que vai adquirir essas mercadorias, porquanto êle, adquirindo essas. mercadorias, pretende revendê-las, pretende especular sôbre a mediação; - e é um ato civil em relação ao produtor, porque êste não especula, comercialmente falando, sôbre a venda que êle opera dos seus produtos. Assim, também, o comerciante a retalho, que vende uma mercadoria a um indivíduo, pratica um ato unilateral, sòmente comercial para êle; êle, revendendo esta mercadoria que comprou com êste fito, pratica um ato comercial, mas o comprador que adquire essa mercadoria, não para revender, mas para aplicar ao seu uso, êste indivíduo pratica um ato unilateral, civil, isto é, em relação a êle é um ato civil. Quando se fala, nesta classificação, de atos unilaterais e de atos bilaterais, leva-se em consideração a pessoa do agente que pratica êstes atos; por conseguinte, todos aquêles atos comerciais que o são, não porque quem os pratica seja comerciante, mas porque êles por sua objetividade entram no quadro dos atos comerciais, êstes atos estão excluidos desta classificação. 
Na nossa legislação, temos no art. 19 do tit. único do Código e no art. 20 do decr. 737 , de 25 de novembro de 1850, exemplos frizantes dêstes atos que são comerciais independentemente da pessoa que os pratica. Assim, segundo o decr. 737 , art. 20, a jurisdição comercial recai sôbre os seguintes atos, muito embora quem os pratica não seja comerciante: todos os atos relativos a letras de câmbio, a riscos, a seguro e a fretamento no D. Marítimo; todos os atos relativos a títulos da divida pública ou de crédito do Estado; todos os atos de Iocação de serviços quando se trata de preço e de tempo determinado. Todos êstes atos são comerciais, não em razão da pessoa que os pratica, mas por determinação expressa da lei. Porisso dissemos atrás que o dr. Carvalho de Mendonça, na sua classificação, incluia entre os atos que são comerciais por fôrça ou autoridade da lei, os atos discriminados no art. 20 do decr. 737. Comparando o art. 20 com o art. 19 que êle pretende regulamentar, nota-se uma discrepância. O art. 19 do título único do Código apenas enumera três casos em que os atos são considerados comerciais independentemente de considerações da pessoa. Qualquer que seja a pessoa que os pratica, seja ou não comerciante, êstes atos estão sujeitos à jurisdição comercial. No decr. 737, entretanto, quem regulamentou a lei de conformidade ou autorizado pelo art. 27 do título único, além dos atos unilaterais do art. 19 , incluiu os atos referentes a riscos, ao fretamento e ao seguro no D. Marítimo.

Os atos unilaterais e bilaterais são contestados por alguns escritores, e a doutrina varia com relação à solução a dar a êstes atos. O alcance prático dessa classificação está nisto: si o ato unilateral, sòmente é comercial para a parte que é comerciante e que o pratica, a que jurisdição se deve submeter o outro indivíduo que entra neste ato, que è parte contratante neste ato, e que pratica um ato civil? Deve-se aplicar-lhe a jurisdição comercial? Esta classificação tem um largo alcance prático para a deter- 
minação das jurisdições. Uma é jurisdição civil e outra é comercial, e, tratando-se duma tal classificação, é preciso chegar-se a esta solução: qual das duas jurisdições é a competente para conhecer das questóes, dos conflitos e colisões resultantes dos atos unilaterais?

No Direito francês são várias as opiniões. Uns entendem que $o$ ato comercial é um ato íntegro, deve ser considerado em tôda a sua integridade, não pode ser separado, cindido, para que uma parte seja regulada pelo $D$. Civil e outra pelo D. Comercial. Assim é que entendem os jurisconsultos desta opinião que tôda a vez que se trata de um ato unilateral, tanto a parte que é comerciante como a que o não é, devem ser sujeitas à jurisdição comercial. Outros entendem, ao contrário, que, sendo o D. Comercial uma exceção ao Direito, uma concessão, tratando-se de um. ato unilateral, é o comerciante que deve sujeitar êsse seu ato à jurisdição civil, porque a jurisdição civil é a regra e a jurisdição comercial é simples exceçẫo. Entendem ainda outros que neste caso deve deixar a opção àquele que vai demandar em juizo acêrca dêste ato unilateral. De modo que se pode dizer que na doutrina do Direito francês não se encontra uma solução precisa e uniforme a respeito de saber a qual das duas jurisdições se deve recorrer quando se trata de questões relativas aos atos unilaterais, e isto porque a legislação francêsa não tem em nenhum dos seus dispositivos uma prescrição clara que mande sujeitar o ato unilateral à jurisdição comercial. Não assim nos códigos modernos, em que o legislador tratou de derimir completamente estas questões que se davam com relação à doutrina dos atos bilaterais e dos unilaterais. $\mathrm{O}$ código italiano no art. 54, o argentino, no art. 7, o alemão, de 1900 , no art. 345 e outros, quando tratam de um ato unilateral, sujeitam-no à jurisdição comercial, a menos que o legislador expressamente não exclua da jurisdição comercial êste ato unilateral. 
À primeira vista parece que o Direito pátrio, o Código Comercial, tendo sido moldado e inspirado principalmente: pelas idéias, pelos princípios, pelo regime, pelo organismo do código francês, também, como êles, deveria deixar sem solução esta questão dos atos unilaterais e bilaterais, quanto à jurisdição que deve ser invocada para dirimir as questões resultantes. Mas o nosso Código não foi bastante claro, embora avançasse um passo sôbre as determinações do Código francês de 1807. Não toi bastante claro nas suas disposições para que se possa considerar resolvida legalmente esta questão da jurisdição que deve ser chamada para dirimir as questões resultantes do ato unilateral. Assim é que se encontram duas opiniões correntes em relação ao Direito pátrio: uma sustentada pelo sr. conselheiro Silva Costa, no seu Tratado de Direito Comercial Marítimo, e outra sustentada pelo dr. Carvalho de MenDONÇ.A.

Entende Silva Costa que o ato é unilateral, isto é, que deve ser submetido, não à jurisdição civil, mas à jurisdição comercial, porque, diz: o ato apresenta dois aspectos distintos - é um ato civil por um lado e por outro é comercial - e apresenta como exemplo o contrato da compra e venda. E acrescenta: as duas partes contratantes que intervêem num ato de compra e venda, são, por um lado, o vendedor, e, por outro, o comprador, ou, suposto o caso em que o vendedor seja comerciante e o comprador não, segue-se que o ato da venda feita pelo comerciante é um ato comercial, e o da compra feita pelo individuo não comerciante é um ato puramente civil. Contestando essa opinião, o dr. Carvalho de Mendonça, aliás não com muita felicidade: apela para os arts. 11 e 12 do decr. 737 de 25 de novembro de 1850. Ora, pror êsses artigos não se resolve de modo claro e preciso a questão de saber qual das jurisdições deve ser invocada para conhecer do ato unilateral de comércio. Com efeito, o art. 11 declara que "não basta para determinar a competência da jurisdição comercial que 
ambas as partes ou alguma delas seja comerciante, mas é essencial que a divida seja também comercial: outrossim, não basta que a dívida seja comercial, mas é essencial que ambas ou uma das partes seja comerciante, salvos os casos e exceções do art. 20". Daí se poderia deduzir que, desde que o legislador sujeita à jurisdição comercial uma obrigação comercial, muito embora uma das partes não seja comerciante, é competente pra conhecer do ato unilateral do comércio a mesma jurisdição comercial. Mas confrontando êste art. 11, que parece estabelecer uma regra geral para todos os atos comerciais com relação à jurisdição que deve conhecer dêles, com o art. 12, nascem dúvidas muito sérias a respeito do pensamento que teve o legislador ao formular o art. 11, pois no art. $12 \mathrm{diz}$ que: "a parte não comerciante é sujeita à jurisdição comercial, ou intervenha no contrato, ou seja herdeiro, sucessor cessionário, subrogado, possuidor de títulos, etc". Ora, si o art. 11 determina que são sujeitas à jurisdição comercial as obrigações comerciais em que alguma ou tôdas as partes que nelas intervêem não sejam comerciantes, parecia inteiramente excusado que pelo art, 12 declarasse que a parte não comerciante está sujeita à jurisdição comercial em tais e tais casos, porque èste caso parecia estar liquidado pela regra geral (si é que o legislador quiz estabelecer uma regra geral). Pelo art. 12 parece, à primeira vista, que o legislador, determinando que a parte não comerciante esteja sujeita à jurisdição comercial em tais e tais casos, parece, a contrario sensu, deduzir ou indicar que, fora dêstes casos expressamente determinados no art. 12, a parte não comerciante não pode estar sujeita à jurisdição comercial. Não tem, piortanto, razão de ser o argumento do dr. Carvalho DE MEndonça quando afirma que os arts. 11 e 12 resolvem perfeitamente a questão; ao contrário, tem razão o dr. Silva Costa quando diz que, tratando-se do ato unilateral do comércio, tanto a parte comerciante como a não comerciante estão sujeitas à jurisdição comercial. 
Estes dois artigos 11 e 12 são, até à primeira vista, contraditórios. A que vem a disposição do art. 11 declarando que a obrigação comercial, embora nesta não intervenha alguma parte comerciante, está sujeita à jurisdição comercial? Se se trata de uma regra geral, a que vem a disposição do art. 12 fazendo especificações? O único meio que há, de conciliá-los, seria admitir que êstes atos a que se refere o art. 12 não são atos comerciais senão em relação à pessôa que os pratica, tem o legislador razão em discriminar êstes atos, apesar de ter determinado que em tôdas as obrigações comerciais as partes devem ser sujeitas à jurisdição comercial.

A conclusão a que queríamos chegar é a seguinte: o dr. Carvalho de Mendonça, quando declara que o ato unilateral de comércio não pode deixar de estar sujeito à jurisdição comercial em virtude da precisa determinação. do legislador no art. 12, não atendeu bem à dificuldade que a interpretação dêsse artigo apresenta, porque êle não é absolutamente claro com relação ao pensamento que o legislador diz nêle introduzir. Por outro lado, diz que o ato linilateral, que êle chama ato bifronte, ato bicolor, é um verdadeiro absurdo em relação à doutrina, e porisso êle não aceita a discriminação feita por Silva Costa em atos bilaterais e atos unilaterais de comércio. O dr. CARvalHo dE MENdonça declara que no nosso Direito e na doutrina não existem atos mistos de comércio. Ainda neste ponto não tem razão.

Quando tratamos de explicar a pròpria natureza das relações do comércio, a relação econômica e a relação jurídica, vimos que os atos comerciais em sua relação econômica apresentavam sempre duas faces distintas: ou eram atos de consumo, ou eram atos de circulação. Se são atos; de circulação, não há dúvida que estão incluídos na jurisdição comercial; si são atos de consumo, pertencem ao círculo da jurisdição civil, porque só é ato de comércio, no dizer de Thaller, o que representa um movimento ou 
um fato de movimento da circulação das riquezas, e aquêle, que adquire uma mercadoria, para aplicá-la às suas próprias necessidades, aquêle que compra um certo produto para consumir, pratica um ato de mero consumo. mas nunca poderá praticar um ato de circulação, um ato de comércio. Mesmo em relação à natureza econômica do comércio, portanto, se apresentam estas duas faces bem distintas. Isto, porém, não quer dizer que o ato de comércio, porque apresenta uma face voltada para o $\mathrm{D}$. Comercial e outra para o D. Civil, deve estar sujeito a duas jurisdições distintas, porque é preciso cbviar ou impedir que haja decisões contraditórias. Se, por exemplo, no contrato de compra e venda, o vendedor, que é comerciante, vai liquidar as condições do contrato em juizo, e chama o comprador a juizo para dirimir essa questão, resultante do ato que êle praticou, o comprador pode, por seu lado, chamar o vendedor comerciante a liquidar a questão derivada dêsse mesmo ato perante a jurisdição civil, e então, sendo duas ações paralelas que correm, era inadmissível que uma fôsse decidida por uma forma e outra por outra forma diferente. Para evitar esta contradiçâo de decisões referentes ao mesmo ato, é que o legislador e a doutrina aquiesceram em que êstes atos, embora sejam por um lado considerados civis e por outro, comerciais. devem ser regidos apenas por uma jurisdição - a comercial. Não é, portanto, porque a nossa lei (que não é expressa) sujeite ếsse ato unilateral à jurisdição comercial. nem mesmo porque não existam atos unilaterais (porque existem por sua própria natureza, não só econômica como jurídica), não é por causa dêsses dois argumentos do dr. Carvalho de Mendonça que os atos são sujeitos à jurisdição comercial, mas sim pelo motivo de evitar que haja sôbre a mesma questão duas decisões, duas sentenças, dois julgados contraditórios. 
Vejamos como os legisladores procederam quando, tratando de determinar o raio de influência do D. Comercial, se viram forçados a determinar quais eram os atos de comércio que se deviam sujeitar às regras, às prescrições do D. Comercial.

No seu relatório apresentado ao parlamento italiano. por ocasião da discussão do projeto do atual Código de 1882, disse o célebre MaNcin que o legislador, para poder cumprir a missão de determinar quais eram os atos comerciais, tinha de seguir invariàvelmente um dêstes caminhos: ou por uma de suas disposições determinar a definição ou a noção do que seja ato de comércio, para nela incluir todos os atos, tôdas as transações, tôdas as operações que entram no domínio do D. Comercial, ou limitar-se a uma simples enumeração dêsses mesmos atos disciplinados pelo D. Comercial. Mas reconheceu-se que o primeiro caso era impossível, porque a ciência, a doutrina, não fornecia elementos capazes para se poder determinar a natureza, a essência, a substância do ato de comércio. de modo que se pudesse formar uma noção ou uma definição exata. Não existindo, pois, essa noção ou definição, ficava-lhe livre o acesso para a enumeração dos atos de comércio, e esta enumeração, por mais minuciosa que fôsse, jamais poderia alcançar todos os atos de comércio que entram na profissão comercial, e que, portanto. devem ser sujeitos à legislação do comércio.

Mas a enumeração ou enunciação dos atos de comércio dos códigos modernos tinha de obdecer a um outro dêstes dois critérios: ou fazer uma enumeração taxativa, restritiva, ou fazer uma enumeração exemplificativa ou compreensiva; queremos dizer: ou conter nas disposições dos códigos e da legislação comercial todos os atos que pertencem ao exercicio do comércio, ou apenas escolher dentre êsses atos alguns mais significativos, mais salientes, para servir de modêlo, de critério quando se tratasse de, em concreto, verificar se o ato é ou não comercial. Alguns 
códigos entendem que essa enumeração deve ser uma enumeração taxativa, de modo que todos aquêles atos de comércio que não sejam expressamente indicados, não sejam atos categorias, não sejam expressamente arrolados na legislação comercial, êstes atos não pertencem ao comércio, não são atos comerciais, e não estão, portanto, sujeitos à legislação comercial. Outros códigos, porém. entendem, e com melhor razão, que basta enumerar: aquêle atos de comércio mais carateristicos, para servir de modêlo, de tipo, quando o poder judiciário seja chamado para, em concreto, resolver se o ato submetido à sua apreciação é ou nâo um ato comercial.

Houve um código que tentou conciliar êstes dois sistemas - o Código Português de 1889 nos seus arts. 202, 203, 204 e 504, nos quais o legislador tratou de determinar, de enunciar, de enumerar os atos que êle reputava como comerciais. No art. 504, para dirimir as dificuldades que pudessem emergir do ato de comércio, enumerou quais eram aquêles atos, aquelas relações juridicas que, em caso algum, poderiam ser considerados como atos de comércio, e, no art. 202, dava uma definição do que fôsse ato de comércio, dizendo que o Código entendia por mercancia: a compra e venda de mercadorias, quer em bruto, quer trabalhadas, quer em grosso, quer a retalho, e também considerava como atos de comércio o aluguel de uso dessas mercadorias. É uma definição inteiramente restrita, inteiramente limitada aos contratos de compra e venda, e que Ferreira Borges reputava das mais exatas.

Outros códigos, porém, não tratam de conciliar, reunir, harmonizar êsses dois sistemas. E êste é o sistema seguido pelos códigos modernos: o Código Italiano, principalmente, em 1882, e com êle o da Rumânia, que lhe é uma cópia servil, o do Chile, o da Argentina, o do Uruguai, o do México - todos êles adotam o sistema da enumeração dos atos de comércio, mas não adotam um mesmo número dos atos de comércio. 
O Código Italiano enumera 24 atos de comércio, e, com êle, o do México, no art. 75; o Argentino enumera apenas 8 ou 10 , e o do Chile enumera 19 , e, assim, os outros códigos. Como se vê, mesmo com relação ao número de atos de comércio que devem ser designados como mais caraterísticos da profissão ou da indústria comercial não são uniformes os códigos. Mas existem atos que pertencem à jurisdição comercial, e que, entretanto, não apresentam o caraterístico, nem da mediação nem da especulação, e, pois, não são atos objetivos, absolutos, são atos relativos ao exercício do comércio, são referentes a uma exploração mercantil; e então êsses códigos, ao passo que enumeravam os atos que entendem ser objetivos de comércio, atos mais caraterísticos de comércio, êles, por uma disposição geral, abrangem, no domínio do $\mathrm{D}$. Comercial, aquêles atos que, sem serem objetivos, são relativos, promovem, facilitam a execução dos atos comerciais pròpriamente ditos. Porisso no Código Italiano, art. 4, depois de ter o legislador enumerado, no art. 3 , vinte e quatro atos de comércio, que êle repútava como mais caraterísticos da indústria comercial, diz que todos os contratos e obrigações do comerciante devem ser presumidos comerciais, uma vez que êstes atos não recaiam sôbre relações exclusivamente civís, e que a sua não referência ao ato comercial resulte do próprio ato. Com esta disposição geral, o Código Italiano e aquêles que o seguiram por modêlo, entenderam abranger todos os atos relativos de comércio, todos aquêles que, não sendo, segundo a escola clássica, comerciais por sua natureza, entram no exercício para promover, facilitar e auxiliar os atos de comércio objetivos. E, depois de ter, por uma disposição geral, abrangido os atos relativos de comércio, ainda declara que todos aquêles atos, praticados por um negociante, devem ser considerados comerciais, salvo quando haja prova em contrário.

O fato da não uniformidade dos códigos na determinaçẩo do número dos atos de comércio é mais uma prova da 
incerteza, da vacilação do legislador quando tratava de enumerar êsses mesmos atos de comércio, - vacilação que se torna mais saliente quando se comparam os atos de comércio enumerados por um código com os enumerados por outro. Basta um exemplo para demonstrar mais esta incerteza do legislador quando trata de catalogar, de dar em quadro os atos que êle considera como de comércio, como atos objetivos e absolutos de comércio. O Código Italiano, por exemplo, considera como comerciais todosi aquêles atos que recaem, não só sôbre bens móveis e semoventes, mas ainda sôbre imóveis, ao passo que a nossa legislação não reconhece que o comércio se possa dar sôbre bens imóveis. E já o Código da Rumânia, cópia do Código Italiano, exclui por completo do comércio tôdas aquelas transações e operações que tenham de recair sôbre bens imóveis ou de raiz. Quaisquer que sejam os matizes que sigam os legisladores ao catalogar os atos de comércio, é êste o sistema geralmente aceito. Há, porém, três códigos modernos que se desviam do rumo geral tomado pelos legisladores quando tratam de determinar ou catalogar os atos de comércio: o Código Alemāo de 1897, o Espanhol de 1885 e o Português de 1889 .

Já vimos atrás que o pensamento diretor que informa tôda a legislação comercial da Alemanha, devido às disposições do Código de 1900, diverge por completo do pensamento diretor dos outros códigos. Para êle não existem atos objetivos de comércio, não existe sistema objecivo para a determinação do ato comércio: volta os olhos, f̊z um retrocesso ao antigo sistema subjetivo, tanto que êle define ato de comércio aquêle que é praticado pelo comerciante no exercício de sua profissäo, de modo que quando êle trata de dar uma noção, uma definição do que seja ato de comércio, e quando trata de caraterizar o comércio, põe de parte o elemento objetivo, para apenas atender à relação pessoal do indivíduo que pratica o ato. Si o inải- 
viduo é comerciante, si pratica o ato no exercicio de sua profissão, o ato praticado é um ato de comércio; mas, si pratica o mesmo alo, nâo no exercício da sua profissão, não para exploração comercial, segundo o art. 283 do Código Alemão, êsse ato não pode ser considerado como comercial. Assim, no art. 3 do título único enumera certas profissôes industriais, e é por isto que êle se limita à enumeração destas operações, não como atos comerciais, mas como uma categoria de matéria que ora pertence a uma exploração profissional, ora a uma exploração mercantil ou comercial.

O Código Espanhol pôs de parte tôda e qualquer enumeração de atos de comércio, e apenas, por uma disposição do art. 3, declara que o legislador reputa atos de comércio todos aquêles que são regulados pelo Código Comercial, e todos aquêles que por sua natureza análoga possam ser considerados comerciais. $\dot{E}$ um sistema empírico, o do Código Espanhol. Não trata de enumerar, de definir, de saber preliminarmente quais são os atos que èle deve sujeitar à legislação comercial: apenas diz que todos os atos que êle enumera, todos os contratos e obrigações que êle inclui na jurisdição comercial, por isso mesmo devem ser considerados como atos comerciais, e como êle poderia deixar de fazer a enumeração de muitos atos comerciais que não estivessem determinados na legislação positiva, êle declara que todos os atos de natureza análoga àqueles que eram legislados pelo Código Comercial devem também, por igual, ser considerados atos comerciais. Êste sistema não deixou de ser seguido pelo Código Português de 1889, que, assim, deixou de parte as tradiçôes do D. Comercial Português. O legislador de 1889 tratou de harmonizar os dois sistemas, de dar uma definição geral do que fôsse ato de comércio, atos por natureza comerciais, seguiu plano inteiramente indiferente: no art. 3 declara que são atos comerciais todos aquêles que são disciplinados pelo Código Comercial. É, pois, o mesmo sis- 
tema do Código Espanhol de 1885. Mas acrescenta que além daqueles atos que são disciplinados pelo Código Comercial, e são ipso-facto considerados comerciais, existem outros, outras obrigacõoes e outros contratos que iambém devem ser regidos pela legislação comercial. E ainda declara que tôdas aquelas obrigaşões, todos aquêles contratos realizados pelo comerciante e que não são de natureza exclusivamente civil, e só por via de referência resultam do próprio ato, êstes atos devem ser considerados como comerciais. As legislações comerciais portuguêsa e espanhola, pondo de parte tôda e qualquer enumeração dos atos de comércio, apenas por uma disposição geral abrangem como comerciais todos aquêles atos que são precisamente regidos, que são precisamente normalizados pela legislação comercial.

À exceção dos Códigos Alemão, Portuguès e Espanhol, todos os outros códigos modernos seguem o sistema da enumeração dos atos de comércio, mas uma enumeração exemplificativa, não uma enumeração taxativa; de modo que todos aquêles atos que, embora não enumerados, ofereçam uma natureza análoga a dos previstos pelo legislador, também devem ser considerados como comerciais.

Vejamos o sistema seguido pela legislação pátria. $O$ nosso Código Comercial de 1850 teve como fontes doutrinais, como modêlo, o Código Francês de 1807, o Holandês de 1830 e o Português de 1833. Foram estas as fontes onde o nosso legislador copiosamente bebeu as disposições do nosso Código. O Código Francês de 1807 foi a primeira dentre as legislações comerciais que tratou de ensaiar uma enumeração inteiramente restrita, pequena; muito poucos atos considera como comerciais. Foi um simples ensaio. Porisso é que todos os doutrinários do direito francês ou dizem que o legislador não teve um critério cientifico vitoriosamente assentado quando tratou de enımerar os atos de comércio, ou foi inteiramente arbitrário. A mesma cousa se pode dizer em globo, do nosso legislador. O Código 
Francês de 1807, nos arts. 632 e 633 , tratou de dar a enumeração dos atos de comércio em: atos de comércio terrestre e atos de comércio marítimo se limitou a muito poucos atos que êle chama carateristicos para servirem de norma ou de modêlo aos outros atos que não enumerou, mas que considerou implicitamente como subjetivos e sujeitos à legislação comercial. O nosso Código seguiu o sistema do legislador francês. Todos os códigos modernos, desde o primeiro artigo, tratam de determinar, de clasificar, de enumerar poucos atos de comércio, que êle incluiu na legislacãa comercial, quando tratou de determinar qual a jurisdição que devia ser invocada para reger os conflitos ou as colisões comerciais resultantes das transaęões, e faz a enumeração dos atos de comércio nos arts. 632 e 633, que são dos últimos artigos.

A mesma cousa se deu em relação ao nosso Código: divide-se em quatro partes, em que trata do comércio terrestre, do comércio marítimo, das formas, e tem um título único, que é uma espécie de apêndice. Neste título único é que o legislador brasileiro iratou de indagar quais eram os aíos comerciais, para sujeitá-los à legislação mercantil, nos arts. 18, 19, 20 e 21.

o legislador que regulamentou o Código, que promulgou o decr. n. 737, de 25 de novembro de 1850 , procurou sujeitar-se a esta norma geral dada pelo legislador no título único do Código, pois determinou que aquelas obrigações, aquêles contratos praticados pelo comerciante no exercício do comércio deviam estar sujeitos à legislação comercial, e declarou ainda mais precisamente que todos os contratos e tôdas as obrigações legisladas ou normalizadas pelo Código Comercial, porisso mesmo deviam ser consideradas comerciais, reproduzindo, portanto, o mesmo sistema do Código Português no art. 1.029, em que essa mesma disposição se encontra, e onde êle diz que tôdas as disposições incluídas no Código Português, porisso mesmo devem ser considerados como comerciais. O nosso legislador não 
seguiu, antes de tudo, um sistema qualquer: é uma legislacão meramente arbitrária. anormal, quando tratou de apurar quais são os atos que êle reputa comerciais, entende como atos de mercancia. De modo que no título único do Código, o legislador por um lado declara que todos os atos, contratos e obrigações contraidas pelo comerciante, e que são incluidas no Códige, são, porisso mesmo, reputados como atos de comércio; por outro lado, no art. 20 enumera alguns atos de comércio que, embora praticados por uma pessoa que não é comerciante, o Código reputa como comerciais. Ora, isto não é sistema para metodizar, enumerar ou enunciar, ao menos por um dispositivo geral, o que seja um ato de comércio. Assim é que o legislador do derr. 737 , de 25 de novembro de 1850 , que foi o célebre estadista EuzÉbio DE QueIroz, desvia-se por completo dos arts. 17, 19 e 21 do tit. único do Código, tratando aparentemente nos caps. $3^{\circ}$ e $4^{\circ}$ de dar uma classificação de atos de comércio, considerando no Código a jurisdição comercial, ora em razão do ato, ora em razão da pessoa, apanhando todos aquêles atos que eram comerciais não só por sua própria natureza, como em razão de serem praticados por um comerciante; e no cap. $4^{\circ}$ tratou de definir a jurisdição comercial em relação aos atos comerciais que só o eram em virtude da sua natureza, de modo que, qualquer que seja a pessoa que pratique êsses atos, êles deviam ser considerados como comerciais ${ }^{-}$e regidos pela legislação comercial. Ora, para se ver que esta classificação nada tem de científica, é arbitrária, basta comparar as disposições do decr. 737, de 25 de novembro de 1850 , com o art. 4. Aí o legislador reproduz como atos que são comerciais por virtude da natureza do próprio ato, atos que êle considerava comerciais. não por natureza do próprio ato, mas em consideração da pessoa que o praticava - confundiu, baralhou completamente a classificação: em um membro colocou uma classe de atos, indo colocar os mesmos atos em um membro diferente. Referimo-nos ao seguro, risco e fretamento 
maritimos. O decr. 737 de 25 de novembro de 1850 , no cap. 3 , que se inscreve: Da jurisdiçâo comercial em razão das pessoas e dos atos, diz no art. 19: Considera-se mercancia: § 4 - Os seguros, fretamentos, risco e quaisquer contratos relativos ao comércio marítimo. De modo que estando incluidos nesse cap. 3 o seguro. o fretamento, etc., como atos que eram comerciais, não só por sua própria natureza, mas em consideração ao agente que os praticou, êle não pcdia declarar êste mesmo seguro, êste mesmo fretamento, nesse capitulo, onde êle trata apenas de apurar a jurisdição comercial en relação exclusivamente aos atos praticados, pondo de parte tôda e qualquer consideração relativa à pesssôa que os pratica. No cap. 4 , art. $20, \S 4$, entretanto, se enumeram, entre aquêles atos que são comerciais por sua natureza, independentemente da pessoa que os pratica, o seguro, o risco, o fretamento marítimos, quando, aliás, no cap. 3 , art. $19, \S 4$, apenas se declara que êsses atos são comerciais, não tanto por sua natureza, mas pela pessoa que os praticou, isto é, que êsseș atos deviam ser considerados comerciais quando eram praticados por comerciantes e recaindo sôbre uma relação objetiva de comércio.

Por êsse exemplo já se vê que o nosso legislador não teve absolutamente em vista organizar um sistema científico, não metodizou uma enumeração de atos de comércio, sistema que êle, aliás, seguiu, e portanto ainda é mais uma razão para não se aceitar a clasificação de atos de comércio do dr. Carvalho de Mendonça, que diz que sôbre o nosso Código Comercial se pode informar, adaptar a sua classificação, porque o nosso Código não seguiu sistema algum, e o demonstra sobejamente o fato de classificar em uma classe atos que foi clasisficar noutra classe diferente.

O assento enumerador da matéria dos atos de comércio do nosso Código é o decr. 737, de 25 de novembro de 1850. Ai se relacionam alguns atos de comércio, atos que são comerciais, não só em razão dêsses mesmos atos, mas 
ainda em razão da pessoa que os pratica. Em primeiro lugar enumera o Código a compra e venda de efeitos semoventes, o que vale excluir da compra e venda comercial aquelas operações que recaem sôbre bens imóveis, sôbre bens de raiz. Mas a compra e venda de efeitos semoventes e móveis pode realizar-se sôbre matéria bruta ou sôłre matéria trabalhada; qualquer que seja a matéria que entra como objeto da compra e venda de efeitos móveis e semoventes, em bruto ou trabalhada, essa compra e venda é comercial uma vez que seja para revender essas mercadorias, em bruto ou trabalhada, por grosso ou a retalho.

Declara ainda como ato de comércio o aluguel de uso de uma cousa. Quem compra uma cousa para alugar o seu uso, pratica um ato comercial, segundo o $\S 1$ do art. 19, do decr. 737. Há um assento que esclarece mais êste assunto, e é o assento de 9 de janeiro de 1857, do Tribunal do Comércio do Rio de Janeiro, declarando que o aluguel de uso de uma cousa só é comercial quando a locação dessa mesma cousa seja considerada mercantil. Mais tarde veremos que os chamados assentos são usos e costumes promulgados pelos antigos tribunais de comércio e juntas comerciais mediante as formalidades que o decr. 737 determina, e que, uma vez publicados, fazem lei, são obrigatórios em todo o Brasil. Este assento de 9 de janeiro de 1857 é um dêstes assentos de usos e costumes comerciais que tem fôrça de lei. Interpretou êste assento o $§ 1$ do art. 19, do decr. 737, quando declara que é ato de comércio o aluguel de uma cousa que se adquiriu para explorar èsse mesmo aluguel, êsse mesmo uso.

O segundo ato de comércio relacionado pelo art. 19 refere-se às operações de câmbio, bancos ou corretagem; o terceiro refere-se às empresas de fábricas comuns, expeđição de mercadorias e espetáculos públicos. e ainda aqui há uma lei posterior estendendo a comercialidade dêstes atos a outros atos de que não cogitou o legislador nesse artigo. Já uma vez nos referimos à lei de 21 de novembro 
de 1903 que organizou os armazẻns gerais, tôdas as operações que se referem a títulos, aos warrants que são emitidos por essas empresas, e também tôdas as compras e vendas que se fazem pùblicamente em feiras ou em leilões, nos armazéns de mercadorias aí depositadas. Temos ainda, em relação ao comércio maritimo, todos os contratos de riscos, todos os contratos que se referem ao seguro, ao fretamento, às expedições de navios, os quais todos são considerados pelo art. 19 como atos de comércio.

\section{Adenda}

Assim se exprime Silva Costa, expendendo a sua doutrina sôbre os atos de comércio: - "Pensamos que os atos de comércio podem ser divididos em:
a) subjetivos;
b) objetivos;
c) mistos;
d) pela teoria do acessório.

Os subjetivos são os que praticam os comerciantes (Cod. Com., tit. único, art. 18; reg. 737, arts. 10, 11, 14 e 19).

Os objetivos são comerciais em razão do próprio ato, sem atenção à qualidade de quem o pratica, como a letra de câmbio (Cod. Com., tit. único, art. 19; reg. 737, art. 20).

Muitos são os atos que têm a natureza civil em relação a um contratante e comercial em relação ao outro; assim, o não comerciante que compra um objeto no estabelecimento comercial, pratica um ato civil - a compra regida pelo D. Civil; e o comerciante, que vende êsse objeto, pratica um ato mercantil - a venda respectiva: se o não comerciante, tem de acionar o comerciante, em razão desta compra e venda, tem de recorrer ao juizo do comércio; si o inverso se der, si o comerciante houver de demandar o comprador não comerciante, em razão dêsse ato, tem de 
recorrer ao juizo civil : é o caso do art. 11 do reg. 737. Eis aqui porque êstes atos são justamente considerados mistos.

Os atos comerciais pela teoria do acessório são da jurisprudência francêsa. são atos de natureza civil; mas que, por sua estreita ligação com os de comércio, recebem dêstes a qualificação: o direito pátrio socorre esta espécie de atos de comércio, quando submete à jurisdição comercial questões de bens de raiz, que ocorrem em execuções comerciais, ou em matéria rescisória. declarando a falência (reg. 737, art. 13)".

\section{V}

Divisões e sub-divisões do comércio: seu valor prático.

Comércio por terra (terrestre); comércio por água (marítimo ou náutico). Regime das águas. Navegação interior (fluvial ou lacustre). Comércio de longo e pequeno curso; cabotagem; colonial; costeagem. 0 comércio de cabotagem no direito pátrio.

O comércio é uma série ininterrupta, contínua, intimamente travada de transações ou de operações do exercicio da troca econômica para a circulação das riquezas, e, conforme às condições em que êsse exercício se manifesta, apresentando feições distintas, surge a necessidade de dividir e subdividir o comércio segundo as condições e as circunstâncias do seu exercício, e que alteram de algum modo as regras e as normas invocadas para regularizar a profissão comercial. O critério para uma classificação do comércio é quadruplo: em primeiro lugar, toma-se em consideração o lugar; em segundo, o tempo; em terceiro, a quantidade das mercadorias que desloca; e, em quarto, - objeto sôbre que recaem as transações comerciais. 
Com relação ao lugar, costuma-se distinguir o comércio em: interno ou interior, externo ou exterior, e em comércio por terra e por água.

Comércio interior é o que se circunscreve ao território de um país, de um estado, de modo a não existir conflito de leis, porque uma só lei rege e disciplina tôdas as transações comerciais interiores.

Uma vez que as nações se circunscrevem aos limites de um território, o comércio, ao conárário, excede êsses limites e relaciona-se com outras nações, dando lugar a conflitos e colisões entre as diferentes legislações, não se sabendo, muitas vezes, ou sendo duvidoso, qual das legisla̧̧ões deve ser aplicada para reger estas ou aquelas relações jurídicas do comércio internacional - eis o comércio exterior.

$O$ comércio interior se divide, entre nós, em: nacional, quando diz respeito ao interêsse nacional do comércio, sem levar em conta as diferentes circunscrições administrativas em que se divide a República; estadúal, quando se limita ao território de um estado; interestadual, quando relaciona o comércio dos diferentes estados entre si; regional, quando limita o seu exercício a um certo ponto do território nacional.

O comércio interior também pode ser público, quando a autoridade públạca intervêm para regularizar as transações comerciais, como nas feiras, mercados, praças de comércio e juntas comerciais; e privado, quando êle é feito entre particulares, entre comerciantes, sem o cunbo oficial, sem a intervenção direta do Estado.

Divide-se ainda o comércio em: comércio por terra e comércio por água. Chama-se comércio por terra ou terrestre aquele que é feito a propósito ou mediante a troca econômica, e comércio por água aquêle que é feito mediante ou a propósito do transporte por água.

Levando-se em conta as circunstâncias de tempo em que se dá, o comércio pode se dividir em: comércio em 
tempo de paz e comércio em tempo de guerra, sendo que o comércio em tempo de guerra é por sua própria natureza restrito, em virtude do direito dos beligerantes em não consentir que os neutros façam contrabando de guerra. Em tempo de paz, porém, o comércio é inteiramente livre.

Em relação à quantidade das mercadorias que desloca, o comércio se divide em: comércio de grosso trato, ou por atacado, ou por grosso. e comércio a retalho ou de pequeno trato.

Em relação ao objeto sòbre que recaem as transações comerciais, são tantas as classificações, debaixo do ponto de vista restrito da qualidade das mercadorias, quantos são os ramos da profissão comercial. Assim se diz que há comércio de compra e venda, de depósito, de transporte, de bancos, de seguros, de câmbio, etc.

De tôdas estas classificações, as que mais de perto afetam o estudo do Direito Comercial privado são aquelas que distribuem o comércio em: comércio marítimo, comércio por água e comércio por terra; aquela que estuda o comércio em relação ao número e quantidade das mercadorias que destoca - o comércio de grosso trato e o de pequeno trato.

Chama-se comércio maritimo ou comércio por água aquele que é feito mediante ou a propósito do transporte por água, por meio da navegação. Esta denominação de comércio marítimo, dada ao comércio que se faz por água, não é a mais correta. Com efeito, se todo o comércio marítimo se limitasse exclusivamente às transações que se fazem a propósito ou meiante a navegação pelo mar, era mais adequada a denominação de maritimo para distinguí-lo. No comércio marítimo, entretanto, se inclui, não só a navegação feita por mar, como a navegação feita pelos rios, que se chama - navegação fluvial, e a feita pelos lagos, que se chama - navegação lacustre.

O comércio marítimo se subdivide em: comércio de fongo curso e de pequeno curso, conforme a extensão da 
navegação que serve a êste comércio. O comércio de pequeno curso ainda se subdivide em: comércio de grande ou de pequena cabotagem, ou em comércio costeiro ou comércio de cabotagem.

Voltando à denominação maritima, dada a êste gênero de comércio, vimo-lhe a impropriedade, por compreender a navegação fluvial e a lacustre. Modernamente, entretanto, principalmente depois da Ordenança de LuIs XVI, e de Colbert, esta denominação de marítimo caiu em uso para estabelecer a diferença que há entre comércio terrestre e comércio impròpriamente dito. Antigamente tôda a população se aglomerava ras costas marítimas do país, e o interior era completamente despovoado. Daí a navegação comercial começar primeiramente pelo mar, para, depois do povoamento progressivo dos territórios, se estender aos rios e lagos interiores do país. Esta é a razão por que antigamente só se dava a denominação de marítimos só se conhecia a navegação feita pelo mar. Mas no Direito Romano e no da Lei Rhodia, ainda não era conhecida esta denominação. Aplicavam a denominação exata, adequada, para distinguir o comércio feito por água do feito por terra .Dêsde a Lei Rhodia, conhecida pelo nome de Lei náutica da ilha de Rhodes, se encontra a denominação dada ao comércio feito por água - comércio náutico. E é esta a denominação aceita no Direito Romano, como se pode ver no Código, livro 4 , tit. 32 , e no Digesto, $1^{\circ} 22$, tit. 2 , e $L^{\circ} 14$, tit. 14. Um dos mais antigos contratos do chamado comércio marítimo, que existem no Direito Romano, eram os empréstimos a risco, ou os empréstimos marítimos ou de câmbio marítimo, que êles chamavam — de náutico faenore, nos textos acima entimerados. Para mais frizar que a denominação técnica de náutico era a mais adequada para aplicar-se ao comércio por água, temos o frag. 9 do Digesto liv. 12 , tit. 2 , onde se trata de um caso interessante de Direitn Marítimo. No Direito Romano não se distingue nitidamente o Direito Comercial Terrestre do Direito Civil 
pròpriamente dito, Estava, entretanto, perfeitamente discriminada a distinção que fazia entre o comércio maritimo e o Direito Civil. Nesse frag. 9 do Digesto, liv. 14, tit. 2 , De lex Rhodia de jactu, trata-se do seguinte caso: naufragara em uma das ilhas Cycladas um navio mercante pertencente a Eudemon de Nicomedia, e uns indivíduos que pagavam imposto aos romanos, e eram chamados - publicanos, assaltaram o navio e roubaram as mercadorias que êle levava. O rei de Nicomedia queixou-se ao imperarador AnTonino desta violação ao seu direito de propriedade. Antonino não quiz dar uma solução jurídica a êste caso, dizendo expressamente que êle, imperador romano, era senhor do mundo, mas que senhor do mar era a Lei Rhodia e, de conformidade com ela. devia ser resolvido o caso apresentado à sua solução. É êste caso veio à baila por aí se não empregar a expressão negócios marítimos, mas a expressão cousas náuticas, rebus nauticis. Esta devia, pois, ser a expressão a usar quando se tratar de comércio por água.

E de grande alcance prático a distinção entre comércio por terra e comércio por água, porque muitas regras e preceitos do comércio por terra não se aplicam ao comércio por água. Daí vem dizerem muitos comercialistas que o Direito Marítimo, isto é. o Direito Comercial Marítimo, é um direito autônomo com relação ao Direito Comercial Terrestre.

A entender literalmente a expressão Direito Comercial Marítimo, poder-se-ia dizer que o comércio feito pela navegação dos lagos e dos rios navegáveis ou flutuáveis, não está submetido às regras do Direito Comercial Marítimo, mas sim ao Direito Comercial Terrestre, porque o maritimo é só aquêle, segundo a etimologia do têrmo, que se exerce por meio da navegaşão por mar. E aí está o interêsse prático da distinção.

Os códigos modernos mantem a denominação comércio maritimo para significar o comércio feito por mar, mas 
imediatamente os códigos apresentam, como o italiano, que trata na parte segunda da sua legislação, - do comércio marítimo e da navegação, abrangendo tudo quanto não diz respeito pròpriamente ao comércio por mar, mas abrangendo o comércio pelos rios, lagos, etc.

O Código Argentino ainda é mais preciso. Quando êle trata, na segunda parte, de dizer quais são as regras comerciais que devem regular o comércio marítimo, não usa da expressão - comércio marítimo, mas faz uma segunda parte e a inscreve: dos direitos e obrigações oriundas da navegação, compreendendo, portanto, tudo quanto diz respeito ao comércio por água, quer êle seja feito por mar, quer em rios ou lagos.

Vejamos o comércio marítimo.

Em relação a êste ponto, divide-se o oceano em duas porções bem distintas: o mar livre ou mar alto, e mar adjacente, mar costeiro, mar litoral, ou mar territorial pròpriamente dito. Chama-se mar territorial adjacente aquela porção de mar que está unida, adjacente, ao litoral dum país.

E diferente o direito. segundo se trata de aplicá-lo ao comércio feito pelo mar litoral ou ao comércio feito pelo mar alto. No mar territorial ou no mar litoral, o Estado exerce, não domínio pròpriamente dito. não a propriedade no rigoroso sentido do Direito Civil, porrque a propriedade, nesse sentido, tem como consequência o exclusivismo; de modo que, se o Estado tivesse sôbre o mar lerritorial ou litoral domínio ou propriedade no senlide indicado, a consequência era que o Estado podia fechar a navegaçäo aos outros paises sôbre o mar territorial, quando verdade é que. embora o mar litoral fique dentro da fiscalização, dentro da esfera da polícia do Estado ribeirinho, é livre, entretanto, para a navegação dos outros Estados, contanto que essa navegação, segundo a expressão técnica de Direito Internacional, seja uma navegação inocente. Mas qual é, portanto, o direito que o Estado ribei- 
rinho exerce sôbre o mar territorial, sôbre essa porção de mar adjacente ao litoral? Simplesmente o direito de vigilância, de soberania, para garantir a sua soberania e acautelar a segurança dos interêsses de seus habitantes, para assegurar e promover os seus interêsses econômicos e aduaneiros. Fóra dêsses direitos, nenhum outro direito pode o Estado ribeirinho exercer sôbre o mar territorial.

Não acontece o mesmo com relação ao mar alto.

Mas como se pode discriminar e balizar esta porção liquida do oceano que se chama mar territorial, e separála do que se chama mar livre? Esta divisão não é indiferente ao Direito, porque não são iguais, uniformes, as regras que o Direito Comercial Marítimo aplica à navegação do mar territorial e do mar alto. Não é possível traçar uma linha fixa sôbre o elemento móvel do mar. Foi preciso, piortanto, procurar uma solução fixa, invariável, para se determinar onde devia começar esta parte líquida que se chama mar territorial, e onde devia ela mesma acabar.

No Direito Romano o mar territorial devia começar na linha do preamar, isto é, no limite máximo a que chegam as marés. No Direito Fenício, ao contrário, o ponto de partida era o baixa mar, isto é, o limite mínimo a que chegam as marés. Modernamente, várias têm sido as soluções apresentadas pelos jurisconsultos para determinar de que extensão, de que largura é esta faixa que constitui o mar territorial. Uns entendiam que devia ser uma extensão de mil milhas (a millha marítima correspondendo a mil oitocentos e cincoenta e dois metros correntes); outros, três e cinco mil milhas; outros, que se devia levar em conta a profundidade das águas para determinar onde começava e onde acabava o mar litoral; e outros que essa extensão devia ser abrangida a ôlho nú. Mas nenhuma destas soluções foi aceita pelo Direito Internacional, quer o Direito Internacional comum, quer o convencional, ou o resultante de tratados entre as diferentes nações. 
Hoje em dia, é solução corrente entre os jurisconsultos que a extensão do mar territorial seja determinada pelo alcance do projétil de um canhão; até onde alcançar o tiro de um canhão disparado da praia, até ai vai o mar territorial, porque, dizem, o mar territorial deve ser aquêle. em que a ocupação pela fôrça armada do Estado ribeirinho seja possível.

O mar territorial pertence à soberania do Estado ribeirinho, está submetido ao seu poder pelo uso que dêle possa tirar, já para pesca, já para a navegação, já para a segurança do território, já para garantir o exercício do comércio e os interêsses econômicos da nação; êste uso é um uso limitado; esta propriedade territorial pode sofrer detenção material, permanente e eficaz da fôrça armada do Estado ribeirinho.

É esta a razão por que se tomou como medida o alcance a que possa chegar o tiro ou um projétil de canhão.

No mar livre não se dá o mesmo: o mar livre ou mar alto é comum, ninguém pode ter soberania sôbre qualquer porção dêste mar. É bem conhecida a grande questão internacional que no comêço dos tempos modernos fêz entrar em conflito a Holanda e a Inglaterra. A Inglaterra, pelo seu poder naval de então, entendia que devia ser a soberana dos mares, regular a navegação do mar livre. impedir que certas nações fizessem o seu percurso mercante pelo mar livre ou mar alto. Contra essa pretensão da Inglaterra, levantou-se a Holanda, que então era um Estado florescente, possuindo uma marinha mercante considerável.

Houve grande discussão entre os jurisconsultos de um e de outro país: uns entendiam que o mar devia ser fechado, mare clausum, e entendiam outros que o mar devia ser aberto, mare liberum, segundo os jurisconsultos da Holanda. 
Hoje essas discussões perderam, de todo, o interêsse jurídico, e têm apenas o interêsse histórico; hoje não há legislação alguma, internacional e pública, que não adote a plena liberdade do mar.

Dêste princípio se derivam as seguintes consequências:

1 - O mar é de uso comum de todos os homens, ninguém pode impedir que uma nação qualquer, no exercício do seu comércio, e mesmo com a sua marinha de guerra, percorra qualquer zona do chamado mar livre ou mar alto.

2 - Não se pode restringir absolutamente o uso comum do mar alto, e quando alguma nação entra em acôrdo particular, faça convenções ou tratados particulares, e imponha nessas convenções alguma restrição ao uso do mar livre, essa restrição não deve ser respeitada pelas outras nações que não foram partes contratantes.

3 - Qualquer que seja o poder naval mercante ou de guerra, das nações, tôdas elas têm o mesmo direito, têm assegurada a mesma faculdade, podem navegar livremente pelo mar alto. Não sucede assim com relação ao mar territorial: o mar territorial não é como o mar alto, um mar de uso inesgotável; é de uso limitado; pode ser efetiva e eficazmente ocupado pelas fôrças navais, pela fôrça armada das nações ribeirinhas; o mar alto, em caso algum, pode ser ocupado, qualquer que seja o poder nava] que pretenda a sua soberania.

A soberania ou o império que exerce o Estado ribeirinho sôbre a zona do oceano que circunda o seu litoral, pode ser de várias espécies: ou êle exerce a chamada polícia de segurança, que é aquela que tem em vista a proibição ou a repressão dos crimes; ou êle exerce a polícia sanitária, que é aquela que, em bem da saúde pública, proibe aos navios pestosos entrarem nos portos dos mares territoriais, pelo perigo do contágio; ou é a polícia aduaneira, isto é, sôbre impostos que o comércio, quer de importação, quer de exportação, costuma o Estado aplicar; 
pode ser um direito ou uma faculdade de jurisdição penal, e isto expressamente se encontra na legislação, qualquer que seja o ramo jurídico que se ocupe da extensão do Direito Positivo pátrio em relação ao espaço.

Como exemplo, pode-se citar o art. 4 do Código Penal.

Tratando-se aí da eficácia da lei penal, isto é, da aplicação da lei penal sôbre o território brasileiro, mencionamse os mares territoriais e os navios mercantes, embora estrangeiros, que estejam ancorados nos seus portos, sôbre os quais o Estado pode exercer, não só a sua polícia de segurança, como a sua polícia sanitária, a polícia aduaneira e a jurisdição penal. 